\title{
Somatic and germline mutations in the pathogenesis of pituitary adenomas
}

\section{Silvia Vandeva', Adrian F Daly², Patrick Petrossians ${ }^{2}$, Sabina Zacharieva ${ }^{1}$ and Albert Beckers ${ }^{2}$}

'Department of Endocrinology, Specialized Hospital for Active Treatment of Endocrinology, Medical University, Sofia, Bulgaria and ${ }^{2}$ Department of Endocrinology, Centre Hospitalaire Universitaire de Liège, Liège Université, Liège, Belgium
Correspondence should be addressed to A Beckers

Email

albert.beckers@chuliege.be

\begin{abstract}
Pituitary adenomas are frequently occurring neoplasms that produce clinically significant disease in 1:1000 of the general population. The pathogenesis of pituitary tumors is a matter of interest as it could help to improve diagnosis and treatment. Until recently, however, disruptions in relatively few genes were known to predispose to pituitary tumor formation. In the last decade, several more genes and pathways have been described. Germline pathogenic variants in the aryl hydrocarbon receptor-interacting protein (AIP) gene were found in familial or sporadic pituitary adenomas, usually with an aggressive clinical course. Cyclin-dependent kinase inhibitor 1B (CDKN1B) pathogenic variants lead to multiple endocrine neoplasia type 4 (MEN4) syndrome, in which pituitary adenomas can occur. Xq26.3 duplications involving the gene GPR101 cause X-linked acrogigantism. The pheochomocytoma and/or paraganglioma with pituitary adenoma association (3PAs) syndrome suggests that pathogenic variants in the genes of the succinate dehydrogenase complex or MYC-associated factor X (MAX) might be involved in pituitary tumorigenesis. New recurrent somatic alterations were also discovered in pituitary adenomas, such as, ubiquitin-specific protease 8 (USP8) and USP48 pathogenic variants in corticotropinomas. The aim of the present review is to provide an overview of the genetic pathophysiology of pituitary adenomas and their clinical relevance.
\end{abstract}

\section{Introduction}

Pituitary adenomas are benign neoplasms that are found in up to $20 \%$ of pituitaries on MRI or autopsy (1), while clinically relevant pituitary adenomas occur in approximately $1: 1000$ people (2). Usually they are monoclonal in origin, expanding from molecular genetic abnormalities in a single somatic cell (3). However, there is evidence demonstrating that pituitary adenomas could be polyclonal, especially recurrent tumors (4). Tumorigenesis involves differential expression of tumor suppressor genes and oncogenes, hormones and growth factors and their receptors, adhesion molecules and microRNAs that lead to disruption of the cell cycle and abnormalities in various signal transduction pathways $(5,6,7,8,9)$. Often, however, the initial trigger of the tumorigenic cascade remains
European Journal of

Endocrinology

(2019) 181, R235-R254 largely unknown. In the last decade significant progress has been made with the discovery of several genetic defects implicated in pituitary tumor pathogenesis in previously recognized or new clinical conditions. Among these newer genetic discoveries are germline pathogenic variants in the aryl hydrocarbon receptor-interacting protein (AIP) gene that were found in familial and sporadic pituitary adenomas (10, 11). Cyclin-dependent kinase inhibitor $1 \mathrm{~B}(C D K N 1 B)$ pathogenic variants were ascribed to a MEN1-like condition, known as MEN4 syndrome (12). Xq26.3 duplications involving the gene GPR101 have been demonstrated in X-linked acrogigantism (X-LAG) (13). The 3P (pheochromocytoma and/or paraganglioma, and pituitary adenoma) association (3PAs) is related to 
pathogenic variants of the succinate dehydrogenase complex genes, among others, and suggests that pheoc hromocytoma/paraganglioma-related genes might rarely cause pituitary adenomas $(14,15)$. Many adenomas arising in the context of germline pathogenic variants or syndromic conditions have an aggressive clinical behavior and show poor responses to standard treatments. However, the prevalence of known germline pathogenic variants in the overall pool of unselected sporadic adenomas is still low $(9,11)$. Regarding somatic pathogenic variants, until recently, only stimulatory guanine nucleotide (GTP)-binding protein alpha (GNAS) pathogenic variants were known to be causally related to somatotropinoma pathogenesis in a sizeable proportion of cases $(16,17)$. Current genomic techniques allowed the identification of other frequently recurrent somatic genetic alterations - phosphatidylinositol 3 kinase alpha subunit (PIK3AC) gene in various types of pituitary adenomas $(18,19)$ and ubiquitin-specific protease 8 (USP8) $(20,21)$ and USP48 gene pathogenic variants in corticotropinomas (22).

\section{Somatic mutations in pituitary adenomas}

\section{GNAS mutations}

The deregulation of the cyclic AMP (cAMP)-protein kinase A (PKA) signaling pathway is strongly implicated in pituitary tumor pathogenesis through different PKAdependent and -independent mechanisms, which together lead to hormonal hypersecretion and cell cycle disruption $(6,23,24)$. One of the most common somatic disruptions seen are activating GNAS gene (OMIM *139320) pathogenic variants, found in about $40 \%$ (up to $63 \%$ in some series) of growth hormone (GH)-producing adenomas and rarely in other pituitary adenoma types $(16,17,25)$. GNAS encodes the gsp oncogene - the stimulatory G-protein subunit alpha (Gs $\alpha)$. The most frequent alterations result in an amino acid substitution of the highly conserved Arg201, and to a lesser extent Gln227, with subsequent constitutive activation of the mutated Gs $\alpha$ subunit, increased adenylate cyclase activity, cAMP production and downstream signaling with abnormal GH transcriptional activation and somatotrope proliferation (26).

GNAS mutation-positive adenomas have been considered to have a favorable clinical profile, including an older age at diagnosis, smaller tumor size, less invasive features and densely granulated microscopic tumor appearance in comparison to their non-mutated counterparts; however, this is not confirmed in all studies $(27,28,29,30,31,32,33,34,35)$. With respect to treatment, and particularly GNAS status in relation to somatostatin responsiveness, the literature is inconsistent. Some studies show a favorable effect of GNAS mutational status (29, $34)$, while others show no effect $(25,28,33,35,36)$. A recent meta-analysis evaluating GH-suppressive responses after an acute octreotide test showed significantly higher GH reduction in the GNAS mutated pituitary adenomas (17). The influence of GNAS pathogenic variants on the long-term somatostatin analogue (SSA) response is also debatable - a better response by measuring GH is reported by some $(30,37)$ but no higher percentage of IGF-1 normalization has been shown by others $(28,31,37)$. Thus, the presence of a GNAS pathogenic variant is one of the many factors that influence the response to SSA treatment (38).

\section{USP8 mutations}

Resistance to the negative glucocorticoid feedback is typical for corticotropinomas. However, somatic pathogenic variants in the nuclear receptor subfamily 3 group C member 1, NR3C1 (OMIM *138040) encoding the glucocorticoid receptor are quite rare $(21,22,39,40,41)$.

In 2014 next-generation sequencing techniques allowed the identification of recurrent somatic pathogenic variants of the USP8 gene (OMIM *603158) in a significant number of corticotropinomas. USP8 is a deubiquitinase that inhibits lysosomal degradation of the EGF receptor (EGFR). Hotspot pathogenic variants in exon 14 affect the binding motif of the protein that regulates its activity, leading to gain of function. USP8 is cleaved, which enhances its catalytic activity, resulting in subsequently impaired downregulation of EGFR and sustained EGF signaling $(20,21)$. In USP8-mutated corticotropinomas, enhanced transcription of proopiomelanocortin (POMC) was observed $(21,42)$. Higher ACTH levels have been demonstrated in USP8-mutated adenomas (20, 43, 44). In another study no absolute difference in ACTH secretion between UPS 8 mutated vs non-mutated tumors was noted, but the smaller size of the mutated adenomas suggested that they had relatively high ACTH production capacity (21). USP8 pathogenic variants have not been found in other pituitary tumor types to date $(21,40,45,46,47,48$, $49,50,51)$.

The overall prevalence of USP8 somatic pathogenic variants is $21-62 \%$ in corticotropinomas $(20,21,42,43$, $52,53,54)$. Females predominate over males in some $(21,42,43,53)$ but not other studies $(54,55)$. In a large 
cohort of 120 corticotropinomas, smaller tumor size and a lower rate of parasellar expansion was reported in USP8-mutated tumors (21). No such correlation was found in other studies $(53,55)$. There is inconsistency regarding differences in basal hormonal values between USP8 mutated and wild-type adenomas (20, 21, 42, 43, 44, $52,53,55)$. In pediatric series, female predominance and an older age at diagnosis of USP8 mutated vs wild-type adenomas was noted (52). In regard to treatment, there is high discrepancy in the cure rates after transsphenoidal adenomectomy - higher remission rates in USP8 mutated adenomas in some studies $(42,53)$, but not in others $(21$, $43,55)$. Higher postoperative free urinary cortisol and ACTH levels were demonstrated in UPS8 mutated patients $(43,44,52)$. Up to 5-year recurrence rates were similar with regard to USP8 mutational status $(21,53)$, although a higher 10-year recurrence rate in USP8 mutated adenomas (58 vs 18\%) was reported recently (55). In pediatric series, higher recurrence rates were also observed in USP8 mutated adenomas (52).

With respect to medical treatment, an enhanced effect of pasireotide might occur due to increased transcript levels of SST5R in USP8 mutated adenomas (42). Another potentially useful therapy could be the EGFR inhibitor gefitinib which reduces ACTH secretion in USP8 mutated adenomas in vitro (21).

\section{USP48 and BRAF mutations}

A recent study described two other recurrently mutated genes in USP8 wild-type adenomas - BRAF (OMIM *164757) and USP48 (OMIM *716445) in 23 and 16.4\% of USP8 wild-type corticotropinomas, respectively (22). There was no clinical difference from wild-type $B R A F /$ USP8 patients, except for the higher midnight ACTH and midnight serum cortisol levels in BRAF V600E-variantharbouring patients. However, as previous studies failed to identify a role of $B R A F$ pathogenic variants in pituitary tumorigenesis $(39,56,57)$, these results need further independent confirmation.

\section{PIK3CA}

Phosphatidylinositol 3-kinase is part of the PI3K/Akt signaling pathway which is implicated in the cell survival, proliferation, adhesion, motility and spread (58). It phosphorylates phosphatidylinositol 4,5-bisphosphate to phosphatidylinositol 3,4,5-triphosphate, which is essential for the phosphorylation of AKT (59). Pathogenic variants in hotspots, located on exons 9 and 20 and amplifications of the PIK3CA gene (OMIM *171834) are found in various tumor types and lead to increased PI3K activity, and subsequent phosphorylation and activation of $\operatorname{AKT}(18,58)$.

Frequent genetic alterations in the PIK3CA gene have been found in various types of pituitary adenomas $(18,19)$. In a Chinese series of 353 pituitary adenomas, 2.3\% harbored somatic PIK3CA pathogenic variants. All of the mutated adenomas were invasive and they constituted $8.8 \%(8 / 91)$ of the invasive tumors in that series (one corticotropinoma, two prolactinomas, four non-functioning adenomas and one plurihormonal adenoma). Furthermore, gene amplifications (defined as copy number of $P I K 3 C A \geq 4)$ were found in $32.9 \%$ (30/91) of invasive and in $26.3 \%$ (69/262) of non-invasive pituitary adenomas, with a similar distribution among different tumor types (18). In a Brazilian cohort, PIK3CA gene mutations were present in $12 \%$ of adenomas (4/33; non-invasive corticotropinoma and 3 invasive nonfunctioning adenomas), while genomic amplifications were found in $21.2 \%$ (7/33) (19). No pathogenic variants in the PIK3CA gene were found in a cohort of GH-secreting adenomas (45).

As PI3K could be a downstream effector of RAS, screening for RAS pathogenic variants has been performed by Lin et al. (18, 59, 60). HRAS (OMIM *190020) pathogenic variants were found in 6.6\% $(6 / 91)$ of the invasive pituitary adenomas, one of which had a co-existent PIK3CA mutation (18). Individual cases of HRAS pathogenic variants were reported by other groups $(61,62,63)$. Regarding the clinical presentation of PIK3CA mutated adenomas, a higher degree of recurrence after surgery has been observed in mutated vs wild-type adenomas: 63 vs 25\% respectively (18).

\section{Whole-exome/genome sequencing}

After the breakthrough discovery of USP8 pathogenic variants in corticotropinomas, several groups reported results from whole-exome/genome sequencing in other pituitary tumor types, confirming the relatively silent somatic landscape $(40,45,46,47,49,50,51)$. However, in two series of GH-secreting adenomas, despite the absence of recurrent somatic pathogenic variants (except GNAS), abnormalities of several different genes involved in $\mathrm{Ca}^{2+}$ $(45,46)$ and cAMP signaling (45) were noted. These studies suggest that disruption of calcium signaling could contribute to somatotropinoma formation. On the basis of data from other human tumor types it was speculated 
that the trigger event could be different in the various tumor types but by targeting the same molecular pathway these could contribute to tumorigenesis $(46,64)$. A recent study identified variants (in two pituitary adenomas each) in several genes (KIF5A, GRB10, LARS, SP100, TRIP12) whose role remains to be further elucidated (40).

\section{Copy number variations}

Frequent copy number variations (CNVs) have also been reported $(40,46,47,50)$. Chromosomal losses are particularly interesting in the context of the two-hit model inactivation of tumor suppressor genes (46). In the absence of subsequent somatic mutation, tumorigenesis might be driven by the coexistence of somatic deletion and epigenetic silencing leading to biallelic inactivation of tumor suppressor genes (46). With respect to the clinical relevance of CNVs, it has been demonstrated that highly genomically disrupted adenomas are more frequently hormonally functional and pathologically atypical, while tumors with rare CNVs are principally non-functional (50). Frequent gains in regions encoding cohesin complex genes have been found, however, without an apparent influence of clinical characteristics of the disrupted adenomas (40). A recent study, focusing on CNVs in pediatric patients with Cushing's disease, showed that $18.5 \%(5 / 27$ samples) had a high degree of chromosomal instability ( $>22 \%$ of the genome). The adenomas with widespread genomic aberrations were significantly larger and had higher rates of invasion of the cavernous sinus (65).

A new approach is that of targeting circulating tumor DNA in the plasma. Using a next-generation sequencing approach, Megnis et al. for the first time detected gene variants in circulating free DNA that were also present in the pituitary adenoma tissue of the same patients (66).

\section{Germline mutations in familial and sporadic pituitary adenomas}

A limited proportion of pituitary adenomas, approximately $5 \%$ arise as part of a heritable or familial syndrome. Such adenomas carry a significant clinical burden as they are usually more aggressive: occur at an early age, have a larger tumor size, show increased invasiveness, and are more likely to demonstrate resistance to standard treatment $(67,68)$. These features determine the need for efficient screening and early recognition.

\section{Familial isolated pituitary adenomas (FIPA)}

Familial pituitary adenomas can be either part of multiple endocrine syndromes or may arise as isolated pituitary adenomas in a familial setting. Over the period 1999-2006 we identified and described familial isolated pituitary adenomas (FIPA) (OMIM \#605555) as a novel condition associated with pituitary adenomas (without the presence of other endocrine neoplasia syndromes) in two or more related members of the same kindred $(69,70)$. FIPA represents around $2 \%$ of all pituitary tumors (70). All types of secreting and non-secreting adenomas are described in FIPA, with a predominance of prolactinomas, somatotropinomas, and non-functioning pituitary adenomas. Kindreds can all share the same pituitary adenoma subtype in affected members (homogeneous FIPA) or different pituitary adenoma subtypes can occur within the same family (heterogeneous FIPA) (70). Notably, pituitary adenomas in the setting of FIPA have some clinical characteristics that distinguish them from sporadic adenomas. In FIPA kindreds, prolactinomas, although most prevalent, have lower frequency in comparison with non-FIPA cases - around 38\%. It could be partly explained by the higher frequency of somatotropinomas (35\%) as compared with the general population of pituitary adenoma patients. FIPA patients usually have earlier disease onset (approximately 4 years) vs non-FIPA cases. In homogenous acromegaly kindreds, the disease onset is early and somatotropinomas are usually large and invasive. Similarly, non-functioning adenomas and prolactinomas in the FIPA setting are larger and more invasive than their non-FIPA counterparts $(11,67,71)$.

\section{AIP mutations in FIPA and sporadic pituitary adenomas}

In 2006 Vierimaa et al. reported that pathogenic variants of the AIP gene (OMIM *605555) were associated with pituitary tumorigenesis in large kindreds in Finland and elsewhere (10). AIP is a tumor suppressor gene located on chromosome 11q13 (10). The gene encodes a 330amino acid cytoplasmic protein - the aryl hydrocarbon receptor (AHR)-interacting protein. Different types of pathogenic variants have been described leading to a truncated protein in many cases $(11,71)$. Besides AHR, AIP has multiple other partners, including chaperones, phosphodiesterases, Gai proteins, survivin, RET, nuclear 
receptors, such as thyroid hormone receptor $\beta 1$, estrogen receptor- $\alpha$, peroxisome proliferator-activated receptor- $\alpha$, viral proteins and others $(11,72,73)$.

The cAMP-PKA signaling pathway is strongly implicated in pituitary tumorigenesis and the loss of AIP in mutated adenomas has been related to increased cAMP signaling through defective inhibitory $\mathrm{G} \alpha$ protein signaling. Furthermore, the loss of AIP has been associated with reduction in Goi-2 protein expression in mutated somatotropinomas $(74,75)$. Loss of this inhibitory $G$ protein signal may be permissive for cellular proliferation and tumor growth. A strongly positive correlation between AIP and Goi-2 protein expression has also been confirmed in sporadic somatotropinomas (73). The complex interplay between AIP and PKA signaling is further supported by the evidence that AIP interacts physically with both the regulatory $(\mathrm{R} 1 \alpha)$ and the catalytic $(\mathrm{C} \alpha)$ subunits of PKA separately, as well as in complex (76). AIP overexpression led to a decrease in nuclear C $\alpha$ expression and total PKA activity. Silencing of AIP resulted in PKA pathway activation, and furthermore, the activation was disproportionately elevated under PDE4specific inhibition, suggesting an additional functional interaction. Of note, the mutant AIP p.R304* interacted to a lesser degree with both PKA subunits (76). Disrupted mutant AIP-PDE4A5 interaction has also been previously reported (77).

Although the role of AHR (the dioxin receptor) in the xenobiotic response has been widely studied, its potential role in the pathogenesis of pituitary adenomas has been recently described (78). Acromegaly was observed with increased incidence in a highly polluted industrial region in Italy (Messina, Sicily) (79). The current prevalence of acromegaly is thought to be 330 cases per million inhabitants and the relative risk of developing the disease was estimated to be eight-fold higher in comparison with a non-polluted area in the same province $(79,80)$. In a subsequent study it was found that 9/23 (39\%) patients from different highly polluted areas in Italy bore a genetic variant of $A H R$ or $A I P$, as compared with $25.3 \%$ (44/187) of patients from non-polluted regions. Notably, genetically variant adenomas in polluted areas had a more severe course of acromegaly, characterized by higher IGF-1 values and larger tumor size and worse response to first-line SSAs in comparison with the other groups (80). It is known that AIP forms a complex with AHR, stabilizing it in the cytoplasm together with a dimer of heat-shock proteins 90 and the co-chaperone p23 and AIP protein expression could influence AHR expression $(78,81,82)$. On the other hand, AHR nuclear translocation can be cAMP dependent
(83), which is the main signaling pathway disruption in AIP silencing. However, the exact mechanisms of the link between AHR and AIP in terms of tumorigenesis in the pituitary remains to be further elucidated.

Large populations of FIPA kindreds, as well as sporadic adenoma patients have been screened for germline pathogenic variants of AIP. AIP mutationpositive carriers, irrespective of the familial status, have certain distinct clinical characteristics in comparison with their mutation-negative counterparts: predominance of somatotropinomas, younger age at diagnosis (about 24.6 years), larger and more invasive adenomas $(11,84)$. In the FIPA setting, AIP pathogenic variants are demonstrated in about $20 \%$ of families, while in cohorts of unselected apparently sporadic pituitary adenomas AIP pathogenic variants are rarely found - in less than $4 \%(11,84)$. However, in young adults (diagnosed $<30$ years of age) with apparently sporadic adenomas (mostly macroadenomas), the prevalence of $A I P$ pathogenic variants was higher, ranging between 1.6 and 13\% $(85,86,87,88,89,90,91$, $92,93)$. Further decreasing the age of diagnosis (pediatric/ adolescent patients $<18$ year/old) increases the frequency of $A I P$ pathogenic variants to $11-25 \%(85,87,94,95$, $96,97,98)$. In our large international cohort of giantism patients, the overall frequency of AIP pathogenic variants was $29 \%$ (99). Another feature related more commonly to AIP mutated adenomas is pituitary apoplexy $(89,100$, $101,102)$, especially in pediatric population (89).

Tumoral AIP protein expression may be low in some somatotropinomas even without AIP pathogenic variants and these tumors can have higher invasive rates (103). Decreased AIP protein staining could potentially serve as a marker of invasive potential, along with more traditional markers such as Ki-67 index and p53 positivity (104).

Apart from the unfavorable clinical characteristics, such as young age and macroadenoma at presentation, AIPmutated adenomas are difficult to treat. In a multicenter collaborative study we demonstrated that although the overall rates of disease control were comparable (70.4 vs $80.5 \%$ for AIP mutated somatotropinomas and controls respectively), AIP-mutated somatotropinomas $(n=75)$ required significantly more neurosurgical interventions than their non-mutated acromegaly counterparts $(n=232)(105)$.

AIP-mutated somatotropinomas appear to be more resistant to first-generation somatostatin analogues, having significantly lower decreases of GH and IGF-1 and less tumor shrinkage $(77,85,105,106,107)$. Pretreatment with octreotide increases AIP protein expression (108, 109), while the role of AIP expression level for SSA 
responsiveness is debatable $(68,103,104,108,109$, 110). Overexpression of wild-type AIP increases ZAC1 expression, while AIP knockdown leads to ZAC1 silencing (108); ZAC1 is known to correlate with IGF-1 reduction and tumor shrinkage under octreotide/lanreotide treatment in acromegaly $(111,112)$. Another causal link was suggested recently through reduced expression of $\mathrm{G}_{\mathrm{i}}$ 2 which mediates somatostatin signaling via the SSTRs (73, 113, 114). Unlike first-generation SSA, similar SSTR5 expression and similar responsiveness to pasireotide irrespective of the AIP expression levels was observed in patients with sporadic acromegaly (107).

Given the well-documented hormonal and tumoral resistance of $A I P$-mutated somatotropinomas to firstgeneration SSAs, treatment with a growth hormone receptor antagonist is an alternative option (115). Such adenomas may also be good candidates for pasireotide treatment. Recently, clinical evidence for long-term pasireotide efficacy in first generation SSA-resistant AIP mutated adenomas has been reported (116). Ten-year treatment with pasireotide LAR in one patient led to hormonal control and significant tumor remnant reduction, which allowed discontinuation of the medication with continuous hormonal control (off therapy) for more than two years currently. Similarly, in a second patient hormonal and tumoral control was observed, but this hormonal control was lost after switching to octreotide. AIP protein and SST2 expression was lost, while SST5 staining was positive on immunohistochemistry in that case (116).

Similarly to somatotropinomas, treatment in $A I P$ mutated prolactinomas is also challenging. Only $40 \%$ $(5 / 12)$ were controlled by dopamine agonists in our multicenter study and 4/7 uncontrolled patients required multiple neurosurgeries (105). The explanation behind the lower responsiveness to DA remains to be further elucidated.

Given the aggressive features of AIP mutated adenomas, questions about genetic screening for index cases and relatives are raised. Based on the more prominent characteristics of AIP mutation-positive adenomas, experts' opinion on the screening referral includes pediatric/adolescent disease onset, pituitary gigantism, FIPA kindreds, macroadenomas (particularly somatotropinomas), occurring $\leq 30$ years of age (117, $118,119)$. Some of the FIPA families (8.3-9.5\%), negative for AIP pathogenic variants by direct sequencing, could have large genomic deletions, which warrants for the use of multiplex ligation-dependent probe amplification
(MLPA) when genetic testing is considered appropriate (98, 100). Recently a clinical risk category system for AIP gene variant screening in pituitary adenomas was proposed, confirming the role of young age at onset (including gigantism), FIPA, macroadenomas and $\mathrm{GH}$ excess as independent risk factors. The highest risk (76\%) was produced combining homogeneous FIPA somatotropinomas families presenting with a macroadenoma at early age ( $<18$ years) and the risk fell significantly when either of the factors (FIPA, macroadenoma or age $>18$ years) was absent (120). However, there are little data on the real-life validity of these recommendations. A recent single tertiaryreferral center study reports after results of AIP and MEN1 pathogenic variants/deletions after applying many of the known characteristics of AIP mutated tumors, in addition to novel factors such as SSA resistance in somatotropinomas, or DA resistance in prolactinomas (68). None of the patients had pathogenic variants/ deletions in AIP or MEN1 genes. In that series most of the pediatric onset patients had Cushing's disease, which reinforces the concept that AIP and MEN1 rarely cause pediatric Cushing's disease. Furthermore, only one patient with gigantism was identified, who did not carry an AIP/MEN1 pathogenic variant. Keeping in mind that the genetic causes are unknown in 50\% of gigantism cases, this result is perhaps not very surprising. The results of that recent study suggest that criteria should be carefully interpreted and applied. The age at onset used to trigger screening for AIP-related pituitary adenomas in sporadic patients could be realistically revised downward to well below 30 years at diagnosis and should focus primarily on extensive and/or invasive macroadenomas (68).

Identifying a germline AIP pathogenic variant raises the need to consider familial genetic screening. Pituitary adenomas in AIP pathogenic variant carriers in this setting has low penetrance of about 20-23\% (71, 105, 121, 122). Screening is guided by the possibility of diagnosing the disease before manifestation as an invasive macroadenoma, which could bring potential treatment benefits $(71,105)$. Genetic screening should be particularly targeted at young (pediatric-adolescent) family members who are at higher risk of developing aggressive adenomas. In pathogenic variant carriers, regular clinical observation is warranted $(11,120,123)$. The screening could start early in life as a patient as young as 6 years of age with preceding clinical symptoms has been diagnosed with an AIP pathogenic variant and pituitary macroadenoma (124). 


\section{X-linked acrogigantism syndrome}

X-LAG syndrome (OMIM \#300942) was described initially in 2014 when a syndrome of early infant-onset pituitary gigantism was linked to microduplications of chromosome Xq26.3 region, encompassing the GPR101 gene (OMIM *300393) $(13,125)$. It is a rare condition and less than 40 cases have been identified so far $(13,125,126$, $127,128,129,130,131)$. Historically, some of the tallest humans bear clinical features suggestive of X-LAG (132). For example, a recent paleogenetic study found increased copy number of the GPR101 gene in an historic giant ( $2 \mathrm{~m}$ $59 \mathrm{~cm}$ ) from the early 20th century (133).

In X-LAG the common duplicated region on chromosome Xq26.3 usually encompasses several genes, among which only GPR101 is differentially overexpressed in the affected pituitary adenoma (13). Indeed, in one $X-L A G$ patient a duplication was identified in which only the GPR101 gene was duplicated (127). Duplications are germline in females and somatic in sporadic males with variable level of mosaicism in the latter $(126,127,130)$. In three families the germline duplication was transmitted from the affected mother to son and all carriers of the duplication had gigantism (131). The GPR101 gene encodes an orphan G protein-coupled receptor (13, 131). The exact mechanisms of tumorigenesis remain to be fully clarified, but there is evidence that the cAMPPKA dependent signaling pathway and increased GHRH secretion could be involved $(129,131,134)$, in addition to other signaling pathways as indicated by transgenic mouse studies (A Beckers \& AF Daly, Personal Communication).

$\mathrm{X}$-LAG syndrome is characterized by some clinical features that discriminate it from other forms of pituitary gigantism. It is a pediatric condition and most of the patients are born with normal height and weight. However, during the first months of their life, as early as 6-12 months, they start to grow excessively and the diagnosis is almost invariably made before the age of 5 years, when their median height standard deviation score (SDS) is about +4-5 SDS, as well as weight +4 SDS. Females prevail over males (2/3 of the cases). Patients have acromegalic features (facial coarsening, including broad nasal bridge, prominent mandible, increased interdental space, and enlarged extremities) and about a third have an increased appetite $(125,126)$. Most of the patients harbor macroadenomas at diagnosis, generally mixed GH- and PRL-secreting tumors, while a minority have hyperplasia alone. A pattern of multiple microadenomatous foci against a hyperplastic background has also been described. The proliferation index of such adenomas is generally low (Ki-67 LI below 3\%) $(125,126,128)$ but if the condition is left untreated it eventually ends with aggressive adenoma progression (128). GH and IGF-1 are markedly elevated at diagnosis, with concomitant hyperprolactinemia in more than $80 \%$ of the patients. Increased levels of GHRH have been detected in some patients, however not to the extent typical for the ectopic GHRH secretion $(13,125,129)$. With respect to treatment, it is complex and a multimodal approach is necessary. Surgery alone can lead to cure but even if GH control is achieved, hypopituitarism remains a life-long burden in many cases. None of the patients responded to first-line somatostatin analogs even at doses typical for adults. The reason for this phenomenon needs to be further clarified as studied tissues from pituitary adenomas of X-LAG patients show preserved SST2 and AIP expression (125). Pegvisomant, alone or in combination, is able to induce IGF-1 normalization $(123,125,126)$. Radiotherapy has been applied in a few of patients with unconvincing effects on hormonal hypersecretion $(125,126)$.

When compared with gigantism in the setting of AIP pathogenic variants or genetically negative cases, X-LAG syndrome could be distinguished by the early childhood or infant onset of disease symptoms, female predominance, presence of acromegalic features at such an early age, increased appetite, marked hormonal hypersecretion, histologically presence of mixed GH-PRL-secreting adenomas and/or hyperplasia; a poor response to SSAs occurs in both AIP mutated and X-LAG-related gigantism $(99,126)$.

In patients with sporadic acromegaly a missense variant has been observed (p.E308D), affecting the intracellular loop 3 of GPR101. It is relatively rare and its role in pituitary pathogenesis is unknown $(13,126,135$, 136, 137). Other missense variants have been detected in prolactinomas and corticotropinomas with unknown impact on tumorigenesis $(137,138)$.

Recently the first prenatally diagnosed case of X-LAG was described, offering a unique prospective observation of the natural course of the disease. The mother had a distant history of acrogigantism starting at 4 months of age with complete cure after the resection of the pituitary adenoma at 24 months. She had typical characteristics of X-LAG and the Xq26.3 microduplication was found at preconception testing. The same genetic abnormality was found in her son on a chorionic villus sample, who grew rapidly and had tumor extirpation at the age of 15 months. The immunohistochemical analysis of both adenomas (mother's and son's) revealed elevated Ki-67 proliferation index, multiple lineage-specific transcription factors and stem cell markers (139). 


\section{Multiple endocrine neoplasia 1 (MEN1)}

MEN1(OMIM \#131100) is a multiorgan disorder including endocrine and non-endocrine tumors. Clinically it is characterized by the occurrence in a patient of at least two of the three following disorders: hyperparathyroidism, pituitary adenoma, and pancreatic neuroendocrine tumors (NETs). Among the other tumor presentations are facial angiofibroma, collagenomas, lipomas, adrenocortical tumors and carcinoid tumors (140). The MEN1 gene (OMIM *613733) is located on chromosome 11q13 and encodes menin, which is a 610 amino-acid nuclear protein $(141,142)$. Menin interacts with various proteins involved in transcriptional regulation, genome stability, cell division and proliferation (143). The disorder has autosomal dominant inheritance with high penetrance and in about $10 \%$ may arise from de novo pathogenic variants (144). Pituitary adenomas occur in about 15-50\% of MEN1 patients $(144,145,146,147,148,149,150,151)$.

The most prevalent pituitary subtypes are prolactinomas (60-80\% of the cases), followed by nonfunctioning pituitary adenomas (in more recent series up to $42 \%$ ), or somatotropinomas (in older series - up to $25 \%)$ and corticotropinomas (<5\%) (144, 146, 147, 148, 149). In rare cases GH hypersecretion could be caused by ectopic GHRH secretion from NETs (152). A distinctive but uncommon feature of MEN1 pituitary adenomas is the plurihormonal profile (especially prolactin-ACTH and/ or GH-positive tumors on immunohistochemistry), as well as the presence of multiple pituitary adenomas (152, $153,154,155)$. In about $15-30 \%$ of patients a pituitary adenoma is the first presentation of MEN1 syndrome (140, $147,148,149)$. Among sporadic pituitary adenomas the occurrence of MEN1 is quite rare - less than $3 \%(152,156$, 157). However, in the pediatric population, similarly to the AIP mutations, the frequency of MEN1 may be higher - up to $6.5 \%(96,97)$ and pituitary adenomas can occur as early as 5 years of age (158). Gigantism due to MEN1 occurs in less than $1 \%$ of all pituitary gigantism cases (99). In the setting of MEN1 with pituitary adenomas, females prevail over males (approximately two-thirds of the cohorts), partly due to the higher prevalence of females with prolactinomas $(148,149,150,151)$. Interestingly, when a pituitary adenoma is the first presentation of the syndrome, MEN1 is more frequently diagnosed in males than females (67.3 vs $44.2 \%$ ) (149) In series including patients before the introduction of routine screening programs MEN1 pituitary adenomas were predominantly macroadenomas (approximately 80\%) and more invasive than their sporadic counterparts $(146,152)$. A recent nationwide
Dutch study of MEN1 pituitary adenomas shows higher frequency of microadenomas - in approximately twothirds of the cases. Notably, approximately half of the adenomas diagnosed in asymptomatic patients by MRI screening were microadenomas. In the absence of tissue confirmation these could represent incidentalomas, which are commonly seen in the general population and could be a source of bias. In that study pituitary adenomas diagnosed clinically prior to the genetic diagnosis of MEN1 were more frequently macroadenomas versus screeningdetected pituitary tumors ( 81.2 vs $46.3 \%, P<0.001)$ and more often functional (70.2 vs $47.0 \%, P=0.009$ ) (148). In the French-Belgium cohort, a poor response to treatment was reported, with normalization of prolactin in only $44 \%$ of the patients (146), while in the Dutch series more that $90 \%$ of the prolactinomas responded to dopamine agonists (148). According to the last guidelines the treatment approach toward MEN1 pituitary adenomas should be identical to non-MEN1 adenomas (144).

However, moving beyond the MEN1 guidelines, due to the high penetrance of the syndrome, the first presentation with pituitary adenoma in up to a third of the patients, and a higher frequency in young patients with aggressive macroadenomas (96, 144, 146, 159), genetic screening for MEN1 (and AIP), could be considered in patients with young onset, invasive macroadenomas.

\section{MEN4}

On genetic testing about $10 \%$ of patients with familial and possibly more sporadic MEN1 cases do not harbor MEN1 pathogenic variants (143). MEN4 (OMIM \#610755) emerged as a new condition in 2006, when pathogenic variants in the CDKN1B gene (OMIM *600778) were described in a family with a MEN1-like phenotype, including acromegaly, primary hyperparathyroidism and other tumors (12). CDKN1B is located on chromosome 12p13 (160) and encodes p27, a cyclin-dependent kinase inhibitor implicated in the regulation of cell cycle progression and arrest $(161,162)$. Up to the present day, CDKN1B germline pathogenic variants explain 1.5-3.7\% of MEN1 negative patients $(163,164,165,166)$. In the setting of MEN4, pituitary adenomas arose in about $37 \%$ of reported cases including somatotropinoma, corticotropinoma, non-functioning pituitary adenoma and prolactinomas, with an age range at onset of 30-79 years (163). In a study of 21 pituitary adenomas (20 corticotropinomas) no somatic $C D K N 1 B$ alterations were present (167). No germline CDKN1B pathogenic variants 
have been found in a series of 88 sporadic or familial pediatric pituitary adenomas (97) and in the FIPA setting it was a very rare and questionable finding (168). Genetic screening for this condition should be probably performed only in MEN1 negative kindreds or individuals and routine screening of patients with isolated pituitary adenomas is unlikely to identify $C D K N 1 B$ mutation carriers.

\section{Carney complex (CNC)}

Carney complex (OMIM \#160980) is a rare autosomal dominant disease that is characterized by the presence of myxomas, spotty skin pigmentation (lentigines) and endocrine hyperactivity $(169,170)$. Some of the most common endocrine abnormalities are primary pigmented nodular adrenocortical disease (PPNAD), pituitary adenomas, thyroid nodules, testicular tumors and ovarian cysts. More than 750 cases have been described to date (171) and most cases have PRKAR1A (OMIM *1888830) pathogenic variants $(172,173)$. Another locus associated with the disease is located on chromosome 2p16 (174) and recently copy number gain at the PRKACB gene locus on chromosome 1p31.1 (OMIM *176892) was described in a patient with abnormal skin pigmentation, myxomas and acromegaly (175). PRKAR1A pathogenic variants lead to loss of function of the protein kinase A $1 \alpha$ regulatory subunit resulting in increased cAMP-dependent PKA activity (171).

In the setting of Carney complex the presentation of pituitary adenomas is generally in the third or fourth decade, and it is usually preceded by other syndromic feature (171). Approximately $75 \%$ of the patients have high but asymptomatic levels of GH, IGF-1 and prolactin with abnormal responses to dynamic testing; however, only up to $12 \%$ develop overt acromegaly, while prolactinomas are rare (176). CNC contributes less than $1 \%$ of gigantism cases (99). In sporadic pituitary adenoma cohorts pathogenic variants of PRKAR1A or in other subunits of PKA do not play frequent role in tumorigenesis $(97,177,178,179)$. In cases with single adenomas surgery could be potentially curative. However, similar to X-LAG, in the setting of $\mathrm{CNC}$, multiple adenomas with surrounding hyperplasia is a known finding $(180,181)$ and clinical management could require partial or total hypophysectomy (181). Medical treatment with somatostatin analogues or a GH receptor antagonist could also be considered (171).

\section{McCune-Albright syndrome}

MAS (OMIM \#174800) is a well-established syndromic condition predisposing to acrogigantism and includes the classic triad of precocious puberty (endocrine hyperactivity), fibrous dysplasia and café-au-lait macules (182, 183). It is caused by a post-zygotic, mosaic, gain-of-function mutations in GNAS and the clinical manifestation is determined by the number of affected tissues, and possibly the timing of the mutation's occurrence $(184,185)$. In the context of MAS, 10-25\% of the patients could have GH hypersecretion leading to gigantism or acromegaly, often accompanied by hyperprolactinemia. MAS accounts for about 5\% of gigantism cases (99). Similarly to CNC and X-LAG, pituitary hyperplasia or a distinct pituitary adenoma could be found in the gland (186, 187, 188, 189). Treatment in these patients is challenging due to various factors: difficult surgical access due to bone thickening, presence of diffuse pituitary hyperplasia, partial response to somatostatin analogues, and the risk of sarcoma transformation of affected bone, following radiotherapy. Treatment with pegvisomant could be useful in such cases $(123,187,188,189,190,191)$.

\section{Pheochromocytoma/paraganglioma and pituitary adenomas association (3PAs)}

The coexistence of these tumors, termed 3PAs (15), is quite rare, although it had been described historically (192). The interrelation between the tumors has been strengthened recently by the finding of a germline $S D H D$ (OMIM *602690) pathogenic variant in a patient with pheochromocytoma, paragangliomas and acromegaly, strengthening a pathogenetic role of the mutation by loss of heterozygosity for SDHD and downregulation of the corresponding protein in the pituitary adenoma tissue (14). Approximately 80 cases with this association have been described in literature and genetic studies in recent cases revealed genetic defects in approximately onethird of cases $(193,194,195,196,197,198)$. Most of the patients had mutations in one of the four genes encoding SDH subunits that are previously known to predispose to pheochromocytoma/paraganglioma (193).

The succinate dehydrogenase complex forms the mitochondrial complex II on the inner mitochondrial membrane and consists of four subunits (A, B, C and D) and an associated assembly factor (SDHAF2). It is responsible for electron transfer in the respiratory chain and converts succinate to fumarate (199). An impaired SDH complex mimics hypoxia, and oncogenesis is likely to be mediated by hypoxia-inducible factor- $1 \alpha$ (HIF- $1 \alpha$ )related pathways (200). 
Clinically, the potentially $S D H x$-mutated pituitary adenomas can be prolactinomas, somatotropinomas or non-functional adenomas. Most are macroadenomas with an aggressive clinical course - requiring surgery and with poor response to somatostatin analogues (193). One carcinoma has been described (196). A distinctive pathologic feature of $S D H x$-mutated pituitary adenomas is an extensive vacuolization of the cytoplasm (201).

Recently, the 3PA syndrome was associated with germline MYC-associated factor X (MAX) (OMIM *154950) pathogenic variants or intragenic deletions in five patients (three prolactinomas and two somatotropinomas) (194, 195, 202). Single cases of 3PAs have also been described in the setting of MEN1, MEN2 or von Hippel-Lindau disease (193) Screening for SDHx mutations in the pool of sporadic pituitary adenomas without personal or familial syndromic history is not warranted as they are quite rare $(15,201,203,204)$. Of note intragenic deletions such as those seen in MAX require MLPA analysis as they are not detectable on Sanger sequencing (195).

\section{Other germline conditions}

Growth hormone excess causing acromegaly or gigantism can rarely be part of neurofibromatosis type 1 (NF1) (OMIM \#162200), characterized by neurofibromas, caféau-lait macules, intertriginous freckling, osseous lesions, Lisch nodules and optic pathway gliomas $(205,206)$. GH hypersecretion with an increase in growth velocity has been observed in about $10 \%$ of children with optic pathway gliomas, which is more frequent than previously thought (207). In accordance with other data in the literature affected children have an optic chiasm tumor but not a pituitary adenoma (207). In such cases the pathogenesis of GH excess has been considered to be either due to loss of somatostatinergic inhibition or presence of overactive GHRH secretion in the optic pathway tumor $(207,208)$. In a series of ten patients with overgrowth and NF1 in the National Institute of Health, including children and adults, a link between pituitary tumorigenesis, NF1 and GH excess has been confirmed. Of note, similarly to MAS and $\mathrm{CNC}$, pituitary hyperplasia has been described in some cases. Given the probability of increased oncological risk, or worsening neurofibromas, pain, or endocrinopathies, it is strongly advisable to investigate NF1 patients for GH excess, including appropriate sellar region and optic tract imaging (208).

Pituitary blastomas (pituitary tumor with embryonic origin) are very rare and can arise in the setting of
DICER1 syndrome (OMIM \#601200), known also as pleuropulmonary blastoma-familial tumor. DICER1 (OMIM *606241) encodes a protein responsible for miRNA maturation. Clinically it presents in early infancy with Cushing's syndrome with high mortality $(9,209$, 210, 211).

Recently, another potential pituitary adenoma predisposition gene has been described - CABLES1 (CDK5 and ABL1 enzyme substrate 1) (OMIM *609194) (212). CABLES1 protein is implicated in negative cell cycle regulation in corticotropes in response to glucocorticoids. Usually the physiologic adrenal-pituitary negative feedback is disrupted in corticotropinomas and CABLES1 protein expression is often lost (213). Given this background, germline and/or tumor DNA samples from an international cohort of 146 pediatric and 35 adult patients was studied for CABLES1 gene variants or copy number variations (212). Four heterozygous missense variants were found in two pediatric and two young adult Cushing's disease patients. Functionally these variants appeared to interfere with the normal inhibition of cell growth by CABLES1 in vitro. The possible tumorigenic mechanism could be linked to increased CDKN1B degradation as all mutated samples showed markedly reduced nuclear CDKN1B staining and preserved, although weaker, CABLES1 immunohistochemical expression. Clinically, all four corticotropinomas were macroadenomas with high Ki-67 index, three of them had extrasellar extension and three required second transsphenoidal surgery (212). Isolated cases of corticotropinomas in the setting of congenital adrenal hyperplasia (OMIM \#201910) with pathogenic variants in the 21-hydroxylase enzyme gene (CYP21A2) (OMIM *613815) and in the setting of $\mathrm{X}$-linked congenital adrenal hypoplasia (OMIM \#300200) with pathogenic variant in the NR0B1 (nuclear receptor subfamily 0 group B member 1) (OMIM *300473) gene have been reported $(214,215,216)$.

\section{Discussion and conclusions}

Scientific progress has led to the discovery of numerous new genetic and genomic disruptions in patients with pituitary tumors. The most frequent genetic causes are summarized in Table 1. While for somatic pathogenic variants discriminative clinical features can be quite subtle, most germline pathogenic variants, though rare, present with particular clinical features. To help prompt diagnosis and treatment, integrated screening could be offered for germline variants (Fig. 1). Pediatric patients 


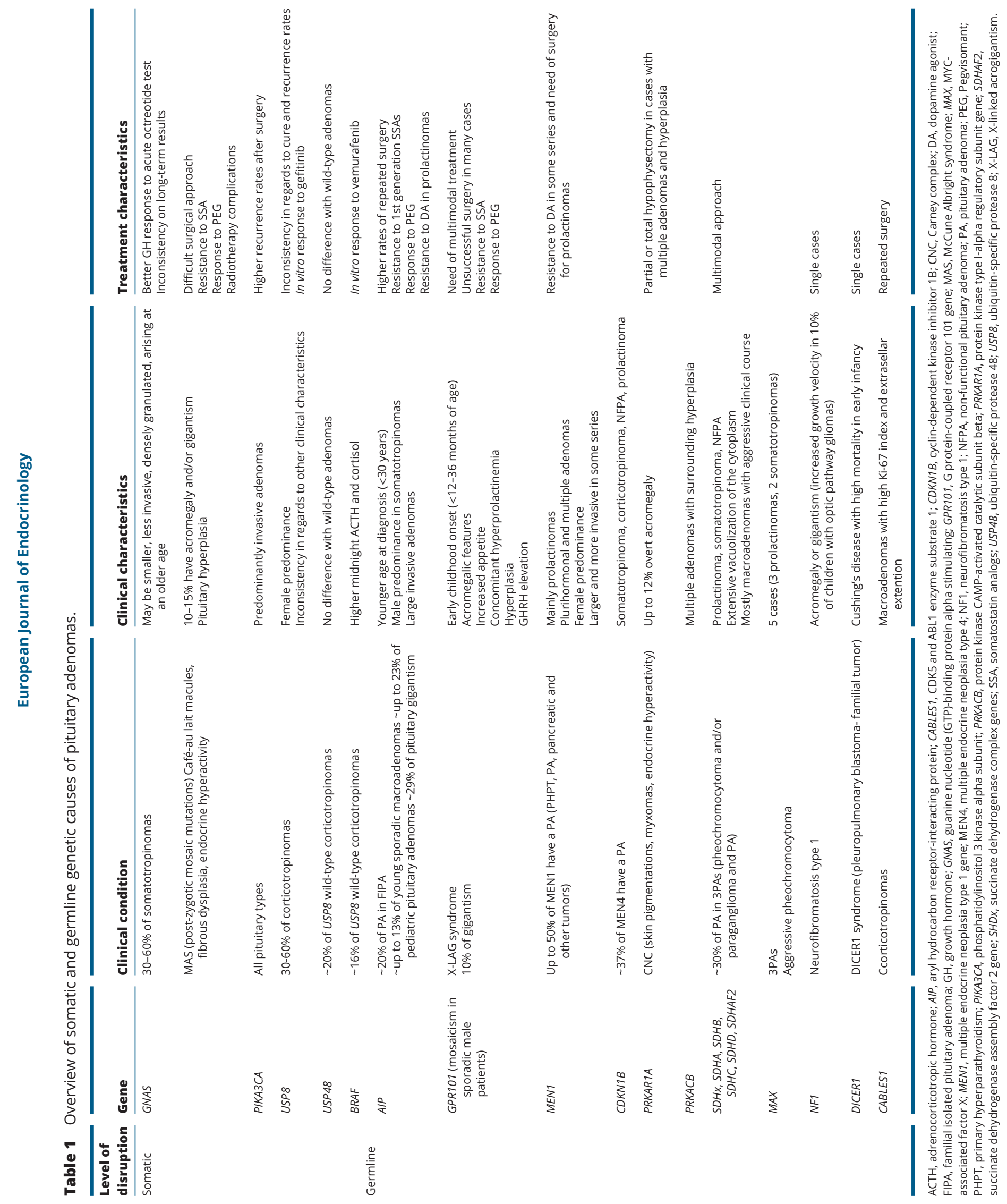




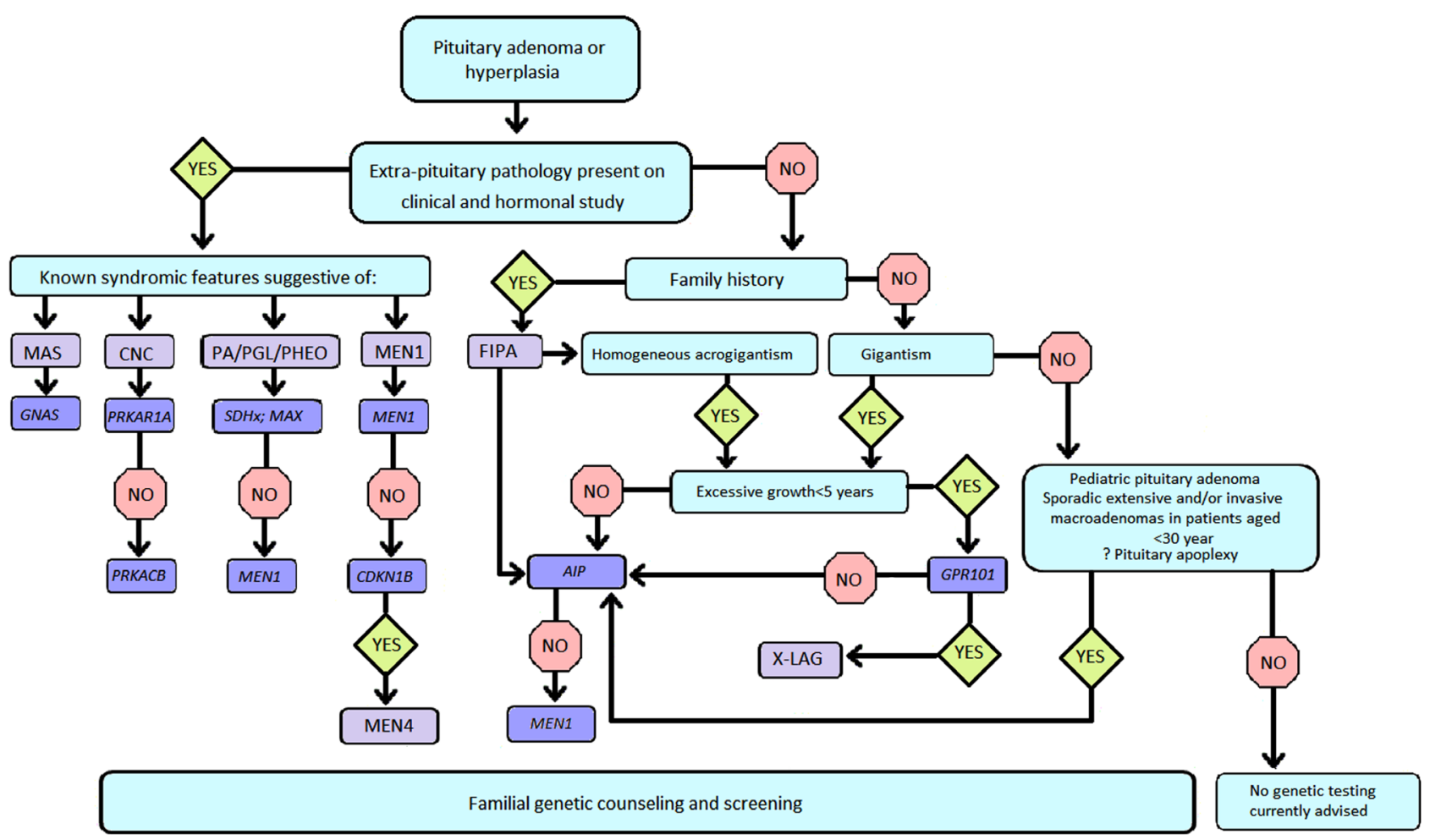

\section{Figure 1}

Screening for genetic causes of pituitary adenomas. AIP, aryl hydrocarbon receptor-interacting protein gene; CDKN1B, cyclindependent kinase inhibitor 1B; CNC, Carney complex; FIPA, familial isolated pituitary adenoma; GNAS, guanine nucleotide (GTP)-binding protein alpha stimulating; GPR101, G protein-coupled receptor 101 gene; MAS, McCune Albright syndrome; MAX, MYC-associated factor X; MEN1, multiple endocrine neoplasia type 1 gene; MEN4, multiple endocrine neoplasia type 4; PA/PGL/ PHEO, pituitary adenoma/paraganlioma/pheochromocytoma; PHPT, primary hyperparathyroidism; PRKACB, Protein Kinase CAMP-Activated Catalytic Subunit Beta; PRKAR1A, protein kinase type I-alpha regulatory subunit gene; SDHAF2, succinate dehydrogenase assembly factor 2 gene; SHDX, succinate dehydrogenase complex genes; X-LAG, X-linked acrogigantism. The figure is adapted by the authors from Rostomyan $L$ and Beckers A. Screening for genetic causes of growth hormone hypersecretion. Growth Hormone and IGF Research 2016 30-31 52-57 with permission.

(up to 18 years) with isolated pituitary adenomas and young adults ( $<30$ years) with isolated aggressive or large pituitary macroadenomas should be screened for AIP and MEN1 gene variants or deletions. Very early-onset cases of somatotropinomas in children that are suggestive for XLAG should be screened for GPR101 duplications via array comparative genome hybridization, and droplet digital PCR can be used for confirmatory purposes. Patients with FIPA should undergo genetic screening for $A I P$ variants/deletions (AIP-negative FIPA families with gigantism cases should be considered for X-LAG screening). Patients or kindreds with MEN1 phenotype without MEN1 pathogenic variants could be screened for CDKN1B gene variants; $C D K N 1 B$ pathogenic variants rarely lead to isolated pituitary adenomas. Genetic screening for Carney complex tends to be guided more by the presence of typical syndromic features rather than any specific characteristics of the pituitary adenomas that occur in Carney complex. The combination of pheochromocytoma and/or paraganglioma and pituitary adenoma could be indicative of $S D H x$ or $M A X$ genetic alterations, including pathogenic variants and deletions. As the availability of multi-gene panels is increasing, a more straightforward approach is to use multigene panels in next-generation sequencing platforms: GNAS, PRKAR1A, MEN1, CDKN1B, $S D H x, M A X$ in patients with concomitant extra-pituitary pathology, and AIP, MEN1 and GPR101 in patients with a familial history of pituitary adenomas or young patients with aggressive adenomas. The relatives of index cases could be offered genetic counseling or screening, or close clinical and radiological surveillance according to the genetic disruption. Prospectively diagnosed mutation 
carriers are managed according to the current guidelines or clinical recommendations for each condition, where they exist.

Apart from clarifying their pathogenesis, new genetic findings provide insight into the clinical characteristics and behaviors of mutated adenoma patients that could discriminate them from the overall population of pituitary adenoma patients and possibly serve as a basis for targeted molecular and individualized treatment approach. Overall the genetic causes of sporadic and hereditary pituitary adenomas are unknown in most cases, which argues for collaborative research studies to identify novel molecular genetic mechanisms.

\section{Declaration of interest}

The authors declare that there is no conflict of interest that could be perceived as prejudicing the impartiality of this review.

\section{Funding}

The work was supported by grants (to $A B$ ) from the JABBS Foundation, UK, the Fonds d'Investissement Pour la Recherche Scientifique of the $\mathrm{CHU}$ de Liège and the Bulgarian Ministry of Education and Science under the National Program for Research "Young Scientist and Postdoctoral Students".

\section{References}

1 Ezzat S, Asa SL, Couldwell WT, Barr CE, Dodge WE, Vance ML \& McCutcheon IE. The prevalence of pituitary adenomas: a systematic review. Cancer 2004101 613-619. (https://doi.org/10.1002/ cncr.20412)

2 Daly AF, Rixhon M, Adam C, Dempegioti A, Tichomirowa MA $\&$ Beckers A. High prevalence of pituitary adenomas: a crosssectional study in the province of Liege, Belgium. Journal of Clinical Endocrinology and Metabolism 200691 4769-4775. (https://doi. org/10.1210/jc.2006-1668)

3 Herman V, Fagin J, Gonsky R, Kovacs K \& Melmed S. Clonal origin of pituitary adenomas. Journal of Clinical Endocrinology and Metabolism 199071 1427-1433. (https://doi.org/10.1210/jcem-71-6-1427)

4 Clayton RN \& Farrell WE. Clonality of pituitary tumours: more complicated than initially envisaged? Brain Pathology 200111 313-327. (https://doi.org/10.1111/j.1750-3639.2001.tb00402.x)

5 Vandeva S, Jaffrain-Rea ML, Daly AF, Tichomirowa M, Zacharieva S $\&$ Beckers A. The genetics of pituitary adenomas. Best Practice and Research: Clinical Endocrinology and Metabolism 201024 461-476. (https://doi.org/10.1016/j.beem.2010.03.001)

6 Xekouki P, Azevedo M \& Stratakis CA. Anterior pituitary adenomas: inherited syndromes, novel genes and molecular pathways. Expert Review of Endocrinology and Metabolism 20105 697-709. (https://doi. org/10.1586/eem.10.47)

7 Zhang T, Yang Z \& Gao H. Advancements in the study of miRNA regulation during the cell cycle in human pituitary adenomas. Journal of Neuro-Oncology 2017134 253-258. (https://doi. org/10.1007/s11060-017-2518-5)

8 Zhou Y, Zhang X \& Klibanski A. Genetic and epigenetic mutations of tumor suppressive genes in sporadic pituitary adenoma. Molecular and Cellular Endocrinology 2014386 16-33. (https://doi.org/10.1016/j. mce.2013.09.006)
9 Marques P \& Korbonits M. Genetic aspects of pituitary adenomas. Endocrinology and Metabolism Clinics of North America 201746 335-374. (https://doi.org/10.1016/j.ecl.2017.01.004)

10 Vierimaa O, Georgitsi M, Lehtonen R, Vahteristo P, Kokko A, Raitila A, Tuppurainen K, Ebeling TM, Salmela PI, Paschke R et al. Pituitary adenoma predisposition caused by germline mutations in the AIP gene. Science 2006312 1228-1230. (https://doi.org/10.1126/ science.1126100)

11 Beckers A, Aaltonen LA, Daly AF \& Karhu A. Familial isolated pituitary adenomas (FIPA) and the pituitary adenoma predisposition due to mutations in the aryl hydrocarbon receptor interacting protein (AIP) gene. Endocrine Reviews 201334 239-277. (https://doi. org/10.1210/er.2012-1013)

12 Pellegata NS, Quintanilla-Martinez L, Siggelkow H, Samson E, Bink K, Hofler H, Fend F, Graw J \& Atkinson MJ. Germ-line mutations in p27Kip1 cause a multiple endocrine neoplasia syndrome in rats and humans. PNAS 2006103 15558-15563. (https://doi.org/10.1073/ pnas.0603877103)

13 Trivellin G, Daly AF, Faucz FR, Yuan B, Rostomyan L, Larco DO, Schernthaner-Reiter MH, Szarek E, Leal LF, Caberg JH et al. Gigantism and acromegaly due to Xq26 microduplications and GPR101 mutation. New England Journal of Medicine $20143712363-2374$. (https://doi.org/10.1056/NEJMoa1408028)

14 Xekouki P, Pacak K, Almeida M, Wassif CA, Rustin P, Nesterova M, de la Luz Sierra M, Matro J, Ball E, Azevedo M et al. Succinate dehydrogenase (SDH) D subunit (SDHD) inactivation in a growthhormone-producing pituitary tumor: a new association for SDH? Journal of Clinical Endocrinology and Metabolism 201297 E357-E366. (https://doi.org/10.1210/jc.2011-1179)

15 Xekouki P, Szarek E, Bullova P, Giubellino A, Quezado M, Mastroyannis SA, Mastorakos P, Wassif CA, Raygada M, Rentia N et al. Pituitary adenoma with paraganglioma/pheochromocytoma (3PAs) and succinate dehydrogenase defects in humans and mice. Journal of Clinical Endocrinology and Metabolism 2015100 E710-E719. (https://doi.org/10.1210/jc.2014-4297)

16 Landis CA, Masters SB, Spada A, Pace AM, Bourne HR \& Vallar L. GTPase inhibiting mutations activate the alpha chain of Gs and stimulate adenylyl cyclase in human pituitary tumours. Nature 1989 340 692-696. (https://doi.org/10.1038/340692a0)

17 Efstathiadou ZA, Bargiota A, Chrisoulidou A, Kanakis G, Papanastasiou L, Theodoropoulou A, Tigas SK, Vassiliadi DA, Alevizaki M \& Tsagarakis S. Impact of gsp mutations in somatotroph pituitary adenomas on growth hormone response to somatostatin analogs: a meta-analysis. Pituitary 201518 861-867. (https://doi. org/10.1007/s11102-015-0662-5)

18 Lin Y, Jiang X, Shen Y, Li M, Ma H, Xing M \& Lu Y. Frequent mutations and amplifications of the PIK3CA gene in pituitary tumors. Endocrine-Related Cancer 200916 301-310. (https://doi. org/10.1677/ERC-08-0167)

19 Murat CB, Braga PB, Fortes MA, Bronstein MD, Correa-Giannella ML \& Giorgi RR. Mutation and genomic amplification of the PIK3CA proto-oncogene in pituitary adenomas. Brazilian Journal of Medical and Biological Research 201245 851-855. (https://doi.org/10.1590/ s0100-879x2012007500115)

20 Reincke M, Sbiera S, Hayakawa A, Theodoropoulou M, Osswald A, Beuschlein F, Meitinger T, Mizuno-Yamasaki E, Kawaguchi K, Saeki Y et al. Mutations in the deubiquitinase gene USP8 cause Cushing's disease. Nature Genetics 201547 31-38. (https://doi.org/10.1038/ ng.3166)

21 Ma ZY, Song ZJ, Chen JH, Wang YF, Li SQ, Zhou LF, Mao Y, Li YM, $\mathrm{Hu}$ RG, Zhang ZY et al. Recurrent gain-of-function USP8 mutations in Cushing's disease. Cell Research 201525 306-317. (https://doi. org/10.1038/cr.2015.20)

22 Chen J, Jian X, Deng S, Ma Z, Shou X, Shen Y, Zhang Q, Song Z, Li Z, Peng $\mathrm{H}$ et al. Identification of recurrent USP48 and BRAF mutations in Cushing's disease. Nature Communications 201893171 . (https:// doi.org/10.1038/s41467-018-05275-5) 
23 Bertherat J, Chanson P \& Montminy M. The cyclic adenosine $3^{\prime}, 5^{\prime}$-monophosphate-responsive factor CREB is constitutively activated in human somatotroph adenomas. Molecular Endocrinology 19959 777-783. (https://doi.org/10.1210/mend.9.7.7476961)

24 Sands WA \& Palmer TM. Regulating gene transcription in response to cyclic AMP elevation. Cellular Signalling 200820 460-466. (https:// doi.org/10.1016/j.cellsig.2007.10.005)

25 Park C, Yang I, Woo J, Kim S, Kim J, Kim Y, Sohn S, Kim E, Lee M, Park H et al. Somatostatin (SRIF) receptor subtype 2 and 5 gene expression in growth hormone-secreting pituitary adenomas: the relationship with endogenous srif activity and response to octreotide. Endocrine Journal 200451 227-236. (https://doi.org/10.1507/endocrj.51.227)

26 Levine MA. Clinical implications of genetic defects in $\mathrm{G}$ proteins: oncogenic mutations in $\mathrm{G}$ alpha s as the molecular basis for the McCune-Albright syndrome. Archives of Medical Research 199930 522-531. (https://doi.org/10.1016/S0188-4409(99)00075-2)

27 Landis CA, Harsh G, Lyons J, Davis RL, McCormick F \& Bourne HR. Clinical characteristics of acromegalic patients whose pituitary tumors contain mutant Gs protein. Journal of Clinical Endocrinology and Metabolism 199071 1416-1420. (https://doi.org/10.1210/jcem71-6-1416)

28 Freda PU, Chung WK, Matsuoka N, Walsh JE, Kanibir MN, Kleinman G, Wang Y, Bruce JN \& Post KD. Analysis of GNAS mutations in 60 growth hormone secreting pituitary tumors: correlation with clinical and pathological characteristics and surgical outcome based on highly sensitive GH and IGF-I criteria for remission. Pituitary 200710 275-282. (https://doi.org/10.1007/ s11102-007-0058-2)

29 Yang I, Park S, Ryu M, Woo J, Kim S, Kim J, Kim Y \& Choi Y. Characteristics of gsp-positive growth hormone-secreting pituitary tumors in Korean acromegalic patients. European Journal of Endocrinology 1996134 720-726. (https://doi.org/10.1530/ eje.0.1340720)

30 Barlier A, Gunz G, Zamora AJ, Morange-Ramos I, Figarella-Branger D, Dufour H, Enjalbert A \& Jaquet P. Pronostic and therapeutic consequences of Gs alpha mutations in somatotroph adenomas. Journal of Clinical Endocrinology and Metabolism 199883 1604-1610. (https://doi.org/10.1210/jcem.83.5.4797)

31 Fougner SL, Casar-Borota O, Heck A, Berg JP \& Bollerslev J. Adenoma granulation pattern correlates with clinical variables and effect of somatostatin analogue treatment in a large series of patients with acromegaly. Clinical Endocrinology 201276 96-102. (https://doi. org/10.1111/j.1365-2265.2011.04163.x)

32 Larkin S, Reddy R, Karavitaki N, Cudlip S, Wass J \& Ansorge O. Granulation pattern, but not GSP or GHR mutation, is associated with clinical characteristics in somatostatin-naive patients with somatotroph adenomas. European Journal of Endocrinology 2013168 491-499. (https://doi.org/10.1530/EJE-12-0864)

33 Kim HJ, Kim MS, Park YJ, Kim SW, Park DJ, Park KS, Kim SY, Cho BY, Lee HK, Jung HW et al. Prevalence of Gs alpha mutations in Korean patients with pituitary adenomas. Journal of Endocrinology $2001 \mathbf{1 6 8}$ 221-226. (https://doi.org/10.1677/joe.0.1680221)

34 Spada A, Arosio M, Bochicchio D, Bazzoni N, Vallar L, Bassetti M \& Faglia G. Clinical, biochemical, and morphological correlates in patients bearing growth hormone-secreting pituitary tumors with or without constitutively active adenylyl cyclase. Journal of Clinical Endocrinology and Metabolism 199071 1421-1426. (https://doi. org/10.1210/jcem-71-6-1421)

35 Yasufuku-Takano J, Takano K, Morita K, Takakura K, Teramoto A $\&$ Fujita T. Does the prevalence of gsp mutations in GH-secreting pituitary adenomas differ geographically or racially? Prevalence of gsp mutations in Japanese patients revisited. Clinical Endocrinology 200664 91-96. (https://doi.org/10.1111/j.1365-2265.2005.02423.x)

36 Fougner SL, Borota OC, Berg JP, Hald JK, Ramm-Pettersen J \& Bollerslev J. The clinical response to somatostatin analogues in acromegaly correlates to the somatostatin receptor subtype $2 \mathrm{a}$ protein expression of the adenoma. Clinical Endocrinology $2008 \mathbf{6 8}$ 458-465. (https://doi.org/10.1111/j.1365-2265.2007.03065.x)

37 Mendoza V, Sosa E, Espinosa-de-Los-Monteros AL, Salcedo M, Guinto G, Cheng S, Sandoval C \& Mercado M. GSPalpha mutations in Mexican patients with acromegaly: potential impact on long term prognosis. Growth Hormone and IGF Research 200515 28-32. (https:// doi.org/10.1016/j.ghir.2004.10.001)

38 Puig Domingo M. Treatment of acromegaly in the era of personalized and predictive medicine. Clinical Endocrinology 2015 83 3-14. (https://doi.org/10.1111/cen.12731)

39 Albani A, Perez-Rivas LG, Reincke M \& Theodoropoulou M. Pathogenesis of Cushing disease: an update on the genetics of corticotropinomas. Endocrine Practice 201824 907-914. (https://doi. org/10.4158/EP-2018-0111)

40 Song ZJ, Reitman ZJ, Ma ZY, Chen JH, Zhang QL, Shou XF, Huang CX, Wang YF, Li SQ, Mao Y et al. The genome-wide mutational landscape of pituitary adenomas. Cell Research 201626 1255-1259. (https://doi.org/10.1038/cr.2016.114)

41 Dahia PL, Honegger J, Reincke M, Jacobs RA, Mirtella A, Fahlbusch R, Besser GM, Chew SL \& Grossman AB. Expression of glucocorticoid receptor gene isoforms in corticotropin-secreting tumors. Journal of Clinical Endocrinology and Metabolism 199782 1088-1093. (https:// doi.org/10.1210/jcem.82.4.3861)

42 Hayashi K, Inoshita N, Kawaguchi K, Ibrahim Ardisasmita A, Suzuki H, Fukuhara N, Okada M, Nishioka H, Takeuchi Y, Komada M et al. The USP8 mutational status may predict drug susceptibility in corticotroph adenomas of Cushing's disease. European Journal of Endocrinology 2016174 213-226. (https://doi.org/10.1530/EJE-150689)

43 Perez-Rivas LG, Theodoropoulou M, Ferrau F, Nusser C, Kawaguchi K, Stratakis CA, Faucz FR, Wildemberg LE, Assie G, Beschorner R et al. The gene of the ubiquitin-specific protease 8 is frequently mutated in adenomas causing Cushing's disease. Journal of Clinical Endocrinology and Metabolism 2015100 E997-1004. (https://doi.org/10.1210/ jc.2015-1453)

44 Perez-Rivas LG, Theodoropoulou M, Puar TH, Fazel J, Stieg MR, Ferrau F, Assie G, Gadelha MR, Deutschbein T, Fragoso MC et al. Somatic USP8 mutations are frequent events in corticotroph tumor progression causing Nelson's tumor. European Journal of Endocrinology 2018178 57-63. (https://doi.org/10.1530/EJE-17-0634)

45 Ronchi CL, Peverelli E, Herterich S, Weigand I, Mantovani G, Schwarzmayr T, Sbiera S, Allolio B, Honegger J, Appenzeller S et al. Landscape of somatic mutations in sporadic GH-secreting pituitary adenomas. European Journal of Endocrinology 2016174 363-372. (https://doi.org/10.1530/EJE-15-1064)

46 Valimaki N, Demir H, Pitkanen E, Kaasinen E, Karppinen A, Kivipelto L, Schalin-Jantti C, Aaltonen LA \& Karhu A. Whole-genome sequencing of growth hormone (GH)-secreting pituitary adenomas. Journal of Clinical Endocrinology and Metabolism 2015100 3918-3927. (https://doi.org/10.1210/jc.2015-3129)

47 Hage M, Viengchareun S, Brunet E, Villa C, Pineau D, Bouligand J, Teglas JP, Adam C, Parker F, Lombes M et al. Genomic alterations and complex subclonal architecture in sporadic GH-secreting pituitary adenomas. Journal of Clinical Endocrinology and Metabolism 2018103 1929-1939. (https://doi.org/10.1210/jc.2017-02287)

48 Newey PJ, Nesbit MA, Rimmer AJ, Head RA, Gorvin CM, Attar M, Gregory L, Wass JA, Buck D, Karavitaki N et al. Whole-exome sequencing studies of nonfunctioning pituitary adenomas. Journal of Clinical Endocrinology and Metabolism 201398 E796-E800. (https:// doi.org/10.1210/jc.2012-4028)

49 Lan X, Gao H, Wang F, Feng J, Bai J, Zhao P, Cao L, Gui S, Gong L \& Zhang Y. Whole-exome sequencing identifies variants in invasive pituitary adenomas. Oncology Letters 201612 2319-2328. (https:// doi.org/10.3892/ol.2016.5029)

50 Bi WL, Horowitz P, Greenwald NF, Abedalthagafi M, Agarwalla PK, Gibson WJ, Mei Y, Schumacher SE, Ben-David U, Chevalier A et al. 
Landscape of genomic alterations in pituitary adenomas. Clinical Cancer Research 201723 1841-1851. (https://doi.org/10.1158/10780432.CCR-16-0790)

51 Sapkota S, Horiguchi K, Tosaka M, Yamada S \& Yamada M. Wholeexome sequencing study of thyrotropin-secreting pituitary adenomas. Journal of Clinical Endocrinology and Metabolism 2017102 566-575. (https://doi.org/10.1210/jc.2016-2261)

52 Faucz FR, Tirosh A, Tatsi C, Berthon A, Hernandez-Ramirez LC, Settas N, Angelousi A, Correa R, Papadakis GZ, Chittiboina P et al. Somatic USP8 gene mutations are a common cause of pediatric Cushing disease. Journal of Clinical Endocrinology and Metabolism 2017 102 2836-2843. (https://doi.org/10.1210/jc.2017-00161)

53 Losa M, Mortini P, Pagnano A, Detomas M, Cassarino MF \& Pecori Giraldi F. Clinical characteristics and surgical outcome in USP8mutated human adrenocorticotropic hormone-secreting pituitary adenomas. Endocrine 201963 240-246. (https://doi.org/10.1007/ s12020-018-1776-0)

54 Ballmann C, Thiel A, Korah HE, Reis AC, Saeger W, Stepanow S, Kohrer K, Reifenberger G, Knobbe-Thomsen CB, Knappe UJ et al. USP8 mutations in pituitary Cushing adenomas-targeted analysis by next-generation sequencing. Journal of the Endocrine Society 20182 266-278. (https://doi.org/10.1210/js.2017-00364)

55 Albani A, Perez-Rivas LG, Dimopoulou C, Zopp S, Colon-Bolea P, Roeber S, Honegger J, Flitsch J, Rachinger W, Buchfelder M et al. The USP8 mutational status may predict long-term remission in patients with Cushing's disease. Clinical Endocrinology 201889 454-458. (https://doi.org/10.1111/cen.13802)

56 De Martino I, Fedele M, Palmieri D, Visone R, Cappabianca P, Wierinckx A, Trouillas J \& Fusco A. B-RAF mutations are a rare event in pituitary adenomas. Journal of Endocrinological Investigation 2007 30 RC1-RC3. (https://doi.org/10.1007/BF03347386)

57 Ewing I, Pedder-Smith S, Franchi G, Ruscica M, Emery M, Vax V, Garcia E, Czirjak S, Hanzely Z, Kola B et al. A mutation and expression analysis of the oncogene BRAF in pituitary adenomas. Clinical Endocrinology 200766 348-352. (https://doi.org/10.1111/ j.1365-2265.2006.02735.x)

58 Samuels Y \& Ericson K. Oncogenic PI3K and its role in cancer. Current Opinion in Oncology 200618 77-82. (https://doi.org/10.1097/01. cco.0000198021.99347.b9)

59 Karakas B, Bachman KE \& Park BH. Mutation of the PIK3CA oncogene in human cancers. British Journal of Cancer 200694 455-459. (https://doi.org/10.1038/sj.bjc.6602970)

60 Suhardja A, Kovacs K \& Rutka J. Genetic basis of pituitary adenoma invasiveness: a review. Journal of Neuro-Oncology 200152 195-204. (https://doi.org/10.1023/a:1010655419332)

61 Karga HJ, Alexander JM, Hedley-Whyte ET, Klibanski A \& Jameson JL. Ras mutations in human pituitary tumors. Journal of Clinical Endocrinology and Metabolism 199274 914-919. (https://doi. org/10.1210/jcem.74.4.1312542)

62 Pei L, Melmed S, Scheithauer B, Kovacs K \& Prager D. H-ras mutations in human pituitary carcinoma metastases. Journal of Clinical Endocrinology and Metabolism 199478 842-846. (https://doi. org/10.1210/jcem.78.4.8157709)

63 Cai WY, Alexander JM, Hedley-Whyte ET, Scheithauer BW, Jameson JL, Zervas NT \& Klibanski A. ras mutations in human prolactinomas and pituitary carcinomas. Journal of Clinical Endocrinology and Metabolism 199478 89-93. (https://doi. org/10.1210/jcem.78.1.8288721)

64 Wood LD, Parsons DW, Jones S, Lin J, Sjoblom T, Leary RJ, Shen D, Boca SM, Barber T, Ptak J et al. The genomic landscapes of human breast and colorectal cancers. Science 2007318 1108-1113. (https:// doi.org/10.1126/science.1145720)

65 Tatsi C, Pankratz N, Lane J, Faucz FR, Hernandez-Ramirez LC, Keil M, Trivellin G, Chittiboina P, Mills JL, Stratakis CA et al. Large genomic aberrations in corticotropinomas are associated with greater aggressiveness. Journal of Clinical Endocrinology and Metabolism 2019 104 1792-1801. (https://doi.org/10.1210/jc.2018-02164)
66 Megnis K, Peculis R, Rovite V, Laksa P, Niedra H, Belcere I, Caune O, Breiksa A, Nazarovs J, Stukens J et al. Evaluation of the possibility to detect circulating tumour DNA from pituitary adenoma. Frontiers in Endocrinology 201910 615. (https://doi.org/10.3389/ fendo.2019.00615)

67 Daly AF \& Beckers A. Familial isolated pituitary adenomas (FIPA) and mutations in the aryl hydrocarbon receptor interacting protein (AIP) gene. Endocrinology and Metabolism Clinics of North America 201544 19-25. (https://doi.org/10.1016/j.ecl.2014.10.002)

68 Daly A, Cano DA, Venegas E, Petrossians P, Dios E, Castermans E, Flores-Martinez A, Bours V, Beckers A \& Soto A. AIP and MEN1 mutations and AIP immunohistochemistry in pituitary adenomas in a tertiary referral center. Endocrine Connections 20198 338-348. (https://doi.org/10.1530/EC-19-0027)

69 Valdes Socin H, Poncin J, Stevens V, Stevenaert A \& Beckers A. Familial isolated pituitary adenomas not linked to somatic MEN-1 mutations. Follow-up of 27 patients. Annales d'Endocrinologiel 2000 61301.

70 Daly AF, Jaffrain-Rea ML, Ciccarelli A, Valdes-Socin H, Rohmer V, Tamburrano G, Borson-Chazot C, Estour B, Ciccarelli E, Brue T et al. Clinical characterization of familial isolated pituitary adenomas. Journal of Clinical Endocrinology and Metabolism 200691 3316-3323. (https://doi.org/10.1210/jc.2005-2671)

71 Hernandez-Ramirez LC, Gabrovska P, Denes J, Stals K, Trivellin G, Tilley D, Ferrau F, Evanson J, Ellard S, Grossman AB et al. Landscape of familial isolated and young-onset pituitary adenomas: prospective diagnosis in AIP mutation carriers. Journal of Clinical Endocrinology and Metabolism 2015100 E1242-E1254. (https://doi.org/10.1210/ jc. 2015-1869)

72 Trivellin G \& Korbonits M. AIP and its interacting partners. Journal of Endocrinology 2011210 137-155. (https://doi.org/10.1530/JOE-110054)

73 Ritvonen E, Pitkanen E, Karppinen A, Vehkavaara S, Demir H, Paetau A, Schalin-Jantti C \& Karhu A. Impact of AIP and inhibitory G protein alpha 2 proteins on clinical features of sporadic GH-secreting pituitary adenomas. European Journal of Endocrinology 2017176 243-252. (https://doi.org/10.1530/EJE-16-0620)

74 Formosa R, Xuereb-Anastasi A \& Vassallo J. Aip regulates cAMP signalling and GH secretion in GH3 cells. Endocrine-Related Cancer 201320 495-505. (https://doi.org/10.1530/ERC-13-0043)

75 Tuominen I, Heliovaara E, Raitila A, Rautiainen MR, Mehine M, Katainen R, Donner I, Aittomaki V, Lehtonen HJ, Ahlsten M et al. AIP inactivation leads to pituitary tumorigenesis through defective Galphai-cAMP signaling. Oncogene 201534 1174-1184. (https://doi. org/10.1038/onc.2014.50)

76 Schernthaner-Reiter MH, Trivellin G \& Stratakis CA. Interaction of AIP with protein kinase A (cAMP-dependent protein kinase). Human Molecular Genetics 201827 2604-2613. (https://doi.org/10.1093/ $\mathrm{hmg} / \mathrm{ddy} 166)$

77 Leontiou CA, Gueorguiev M, van der Spuy J, Quinton R, Lolli F, Hassan S, Chahal HS, Igreja SC, Jordan S, Rowe J et al. The role of the aryl hydrocarbon receptor-interacting protein gene in familial and sporadic pituitary adenomas. Journal of Clinical Endocrinology and Metabolism 200893 2390-2401. (https://doi.org/10.1210/jc.2007-2611)

78 Cannavo S, Trimarchi F \& Ferrau F. Acromegaly, genetic variants of the aryl hydrocarbon receptor pathway and environmental burden. Molecular and Cellular Endocrinology 2017457 81-88. (https://doi. org/10.1016/j.mce.2016.12.019)

79 Cannavo S, Ferrau F, Ragonese M, Curto L, Torre ML, Magistri M, Marchese A, Alibrandi A \& Trimarchi F. Increased prevalence of acromegaly in a highly polluted area. European Journal of Endocrinology 2010163 509-513. (https://doi.org/10.1530/EJE-10-0465)

80 Cannavo S, Ragonese M, Puglisi S, Romeo PD, Torre ML, Alibrandi A, Scaroni C, Occhi G, Ceccato F, Regazzo D et al. Acromegaly is more severe in patients with AHR or AIP gene variants living in highly polluted areas. Journal of Clinical Endocrinology and Metabolism 2016 101 1872-1879. (https://doi.org/10.1210/jc.2015-4191) 
81 Bell DR \& Poland A. Binding of aryl hydrocarbon receptor (AhR) to AhR-interacting protein. The role of hsp90. Journal of Biological Chemistry 2000275 36407-36414. (https://doi.org/10.1074/jbc. M004236200)

82 Lees MJ, Peet DJ \& Whitelaw ML. Defining the role for XAP2 in stabilization of the dioxin receptor. Journal of Biological Chemistry 2003278 35878-35888. (https://doi.org/10.1074/jbc.M302430200)

83 Oesch-Bartlomowicz B, Huelster A, Wiss O, Antoniou-Lipfert P, Dietrich C, Arand M, Weiss C, Bockamp E \& Oesch F. Aryl hydrocarbon receptor activation by cAMP vs. dioxin: divergent signaling pathways. PNAS 2005102 9218-9223. (https://doi. org/10.1073/pnas.0503488102)

84 Iacovazzo D, Hernandez-Ramirez LC \& Korbonits M. Sporadic pituitary adenomas: the role of germline mutations and recommendations for genetic screening. Expert Review of Endocrinology and Metabolism 201712 143-153. (https://doi.org/10.1 080/17446651.2017.1306439)

85 Tichomirowa MA, Barlier A, Daly AF, Jaffrain-Rea ML, Ronchi C, Yaneva M, Urban JD, Petrossians P, Elenkova A, Tabarin A et al. High prevalence of AIP gene mutations following focused screening in young patients with sporadic pituitary macroadenomas. European Journal of Endocrinology 2011165 509-515. (https://doi.org/10.1530/ EJE-11-0304)

86 Preda V, Korbonits M, Cudlip S, Karavitaki N \& Grossman AB. Low rate of germline AIP mutations in patients with apparently sporadic pituitary adenomas before the age of 40: a single-centre adult cohort. European Journal of Endocrinology 2014171 659-666. (https://doi. org/10.1530/EJE-14-0426)

87 Cai F, Zhang YD, Zhao X, Yang YK, Ma SH, Dai CX, Liu XH, Yao Y, Feng M, Wei JJ et al. Screening for AIP gene mutations in a Han Chinese pituitary adenoma cohort followed by LOH analysis. European Journal of Endocrinology 2013169 867-884. (https://doi. org/10.1530/EJE-13-0442)

88 Schofl C, Honegger J, Droste M, Grussendorf M, Finke R, Plockinger U, Berg C, Willenberg HS, Lammert A, Klingmuller D et al. Frequency of AIP gene mutations in young patients with acromegaly: a registry-based study. Journal of Clinical Endocrinology and Metabolism 201499 E2789-E2793. (https://doi.org/10.1210/jc.2014-2094)

89 Hernandez-Ramirez LC, Gabrovska P, Denes J, Stals K, Trivellin G, Tilley D, Ferrau F, Evanson J, Ellard S, Grossman AB et al. Landscape of familial isolated and young-onset pituitary adenomas: prospective diagnosis in AIP mutation carriers. Journal of Clinical Endocrinology and Metabolism 2015100 E1242-E1254. (https://doi.org/10.1210/ jc.2015-1869)

90 Karaca Z, Taheri S, Tanriverdi F, Unluhizarci K \& Kelestimur F. Prevalence of AIP mutations in a series of Turkish acromegalic patients: are synonymous AIP mutations relevant? Pituitary 201518 831-837. (https://doi.org/10.1007/s11102-015-0659-0)

91 Ramirez-Renteria C, Hernandez-Ramirez LC, Portocarrero-Ortiz L, Vargas G, Melgar V, Espinosa E, Espinosa-de-Los-Monteros AL, Sosa E, Gonzalez B, Zuniga S et al. AIP mutations in young patients with acromegaly and the Tampico Giant: the Mexican experience. Endocrine 201653 402-411. (https://doi.org/10.1007/s12020-0160930-9)

92 De Sousa SMC, McCabe MJ, Wu K, Roscioli T, Gayevskiy V, Brook K, Rawlings L, Scott HS, Thompson TJ, Earls P et al. Germline variants in familial pituitary tumour syndrome genes are common in young patients and families with additional endocrine tumours. European Journal of Endocrinology 2017176 635-644. (https://doi.org/10.1530/ EJE-16-0944)

93 Tuncer FN, Dogansen SÇ, Serbest E, Tanrikulu S, Ekici Y, Bilgic B \& Yarman S. Screening of AIP gene variations in a cohort of Turkish patients with young-onset sporadic hormone-secreting pituitary adenomas. Genetic Testing and Molecular Biomarkers 201822 702-708. (https://doi.org/10.1089/gtmb.2018.0133)

94 Cazabat L, Bouligand J, Salenave S, Bernier M, Gaillard S, Parker F, Young J, Guiochon-Mantel A \& Chanson P. Germline AIP mutations in apparently sporadic pituitary adenomas: prevalence in a prospective single-center cohort of 443 patients. Journal of Clinical Endocrinology and Metabolism 201297 E663-E670. (https://doi. org/10.1210/jc.2011-2291)

95 Cazabat L, Bouligand J \& Chanson P. AIP mutation in pituitary adenomas. New England Journal of Medicine 2011364 1973-1974; author reply 1974. (https://doi.org/10.1056/NEJMc1101859)

96 Cuny T, Pertuit M, Sahnoun-Fathallah M, Daly A, Occhi G, Odou MF, Tabarin A, Nunes ML, Delemer B, Rohmer V et al. Genetic analysis in young patients with sporadic pituitary macroadenomas: besides AIP don't forget MEN1 genetic analysis. European Journal of Endocrinology 2013168 533-541. (https://doi.org/10.1530/EJE-12-0763)

97 Stratakis CA, Tichomirowa MA, Boikos S, Azevedo MF, Lodish M, Martari M, Verma S, Daly AF, Raygada M, Keil MF et al. The role of germline AIP, MEN1, PRKAR1A, CDKN1B and CDKN2C mutations in causing pituitary adenomas in a large cohort of children, adolescents, and patients with genetic syndromes. Clinical Genetics 201078 457-463. (https://doi.org/10.1111/j.1399-0004.2010.01406.x)

98 Georgitsi M, De Menis E, Cannavo S, Makinen MJ, Tuppurainen K, Pauletto P, Curto L, Weil RJ, Paschke R, Zielinski G et al. Aryl hydrocarbon receptor interacting protein (AIP) gene mutation analysis in children and adolescents with sporadic pituitary adenomas. Clinical Endocrinology 200869 621-627. (https://doi. org/10.1111/j.1365-2265.2008.03266.x)

99 Rostomyan L, Daly AF, Petrossians P, Nachev E, Lila AR, Lecoq AL, Lecumberri B, Trivellin G, Salvatori R, Moraitis AG et al. Clinical and genetic characterization of pituitary gigantism: an international collaborative study in 208 patients. Endocrine-Related Cancer 201522 745-757. (https://doi.org/10.1530/ERC-15-0320)

100 Igreja S, Chahal HS, King P, Bolger GB, Srirangalingam U, Guasti L, Chapple JP, Trivellin G, Gueorguiev M, Guegan K et al. Characterization of aryl hydrocarbon receptor interacting protein (AIP) mutations in familial isolated pituitary adenoma families. Human Mutation 201031 950-960. (https://doi.org/10.1002/ humu.21292)

101 Villa C, Lagonigro MS, Magri F, Koziak M, Jaffrain-Rea ML, Brauner R, Bouligand J, Junier MP, Di Rocco F, Sainte-Rose C et al. Hyperplasiaadenoma sequence in pituitary tumorigenesis related to aryl hydrocarbon receptor interacting protein gene mutation. EndocrineRelated Cancer 201118 347-356. (https://doi.org/10.1530/ERC-110059)

102 Xekouki P, Mastroyiannis SA, Avgeropoulos D, de la Luz Sierra M, Trivellin G, Gourgari EA, Lyssikatos C, Quezado M, Patronas N, Kanaka-Gantenbein $\mathrm{C}$ et al. Familial pituitary apoplexy as the only presentation of a novel AIP mutation. Endocrine-Related Cancer 2013 20 L11-L14. (https://doi.org/10.1530/ERC-13-0218)

103 Jaffrain-Rea ML, Angelini M, Gargano D, Tichomirowa MA, Daly AF, Vanbellinghen JF, D'Innocenzo E, Barlier A, Giangaspero F, Esposito V et al. Expression of aryl hydrocarbon receptor (AHR) and AHR-interacting protein in pituitary adenomas: pathological and clinical implications. Endocrine-Related Cancer 200916 1029-1043. (https://doi.org/10.1677/ERC-09-0094)

104 Kasuki Jomori de Pinho L, Vieira Neto L, Armondi Wildemberg LE, Gasparetto EL, Marcondes J, de Almeida Nunes B, Takiya CM \& Gadelha MR. Low aryl hydrocarbon receptor-interacting protein expression is a better marker of invasiveness in somatotropinomas than Ki-67 and p53. Neuroendocrinology 201194 39-48. (https://doi. org/10.1159/000322787)

105 Daly AF, Tichomirowa MA, Petrossians P, Heliovaara E, JaffrainRea ML, Barlier A, Naves LA, Ebeling T, Karhu A, Raappana A et al. Clinical characteristics and therapeutic responses in patients with germ-line AIP mutations and pituitary adenomas: an international collaborative study. Journal of Clinical Endocrinology and Metabolism 201095 E373-E383. (https://doi.org/10.1210/jc.2009-2556)

106 Oriola J, Lucas T, Halperin I, Mora M, Perales MJ, AlvarezEscola C, Paz de de MN, Diaz Soto G, Salinas I, Julian MT et al. Germline mutations of AIP gene in somatotropinomas resistant to 
somatostatin analogues. European Journal of Endocrinology 2013168 9-13. (https://doi.org/10.1530/EJE-12-0457)

107 Iacovazzo D, Carlsen E, Lugli F, Chiloiro S, Piacentini S, Bianchi A, Giampietro A, Mormando M, Clear AJ, Doglietto F et al. Factors predicting pasireotide responsiveness in somatotroph pituitary adenomas resistant to first-generation somatostatin analogues: an immunohistochemical study. European Journal of Endocrinology 2016 174 241-250. (https://doi.org/10.1530/EJE-15-0832)

108 Chahal HS, Trivellin G, Leontiou CA, Alband N, Fowkes RC, Tahir A, Igreja SC, Chapple JP, Jordan S, Lupp A et al. Somatostatin analogs modulate AIP in somatotroph adenomas: the role of the ZAC1 pathway. Journal of Clinical Endocrinology and Metabolism 201297 E1411-E1420. (https://doi.org/10.1210/jc.2012-1111)

109 Jaffrain-Rea ML, Rotondi S, Turchi A, Occhi G, Barlier A, Peverelli E, Rostomyan L, Defilles C, Angelini M, Oliva MA et al. Somatostatin analogues increase AIP expression in somatotropinomas, irrespective of Gsp mutations. Endocrine-Related Cancer 201320 753-766. (https://doi.org/10.1530/ERC-12-0322)

110 Kasuki L, Vieira Neto L, Wildemberg LE, Colli LM, de Castro M, Takiya CM \& Gadelha MR. AIP expression in sporadic somatotropinomas is a predictor of the response to octreotide LAR therapy independent of SSTR2 expression. Endocrine-Related Cancer 201219 L25-L29. (https://doi.org/10.1530/ERC-12-0020)

111 Theodoropoulou M, Tichomirowa MA, Sievers C, Yassouridis A, Arzberger T, Hougrand O, Deprez M, Daly AF, Petrossians P, Pagotto U et al. Tumor ZAC1 expression is associated with the response to somatostatin analog therapy in patients with acromegaly. International Journal of Cancer 2009125 2122-2126. (https://doi. org/10.1002/ijc.24602)

112 Theodoropoulou M, Zhang J, Laupheimer S, Paez-Pereda M, Erneux C, Florio T, Pagotto U \& Stalla GK. Octreotide, a somatostatin analogue, mediates its antiproliferative action in pituitary tumor cells by altering phosphatidylinositol 3-kinase signaling and inducing Zac1 expression. Cancer Research 200666 1576-1582. (https://doi. org/10.1158/0008-5472.CAN-05-1189)

113 Birnbaumer L. Receptor-to-effector signaling through G proteins: roles for beta gamma dimers as well as alpha subunits. Cell 199271 1069-1072. (https://doi.org/10.1016/s0092-8674(05)80056-x)

114 Zatelli MC, Piccin D, Tagliati F, Ambrosio MR, Margutti A, Padovani R, Scanarini M, Culler MD \& degli Uberti EC. Somatostatin receptor subtype 1 selective activation in human growth hormone (GH)- and prolactin (PRL)-secreting pituitary adenomas: effects on cell viability, GH, and PRL secretion. Journal of Clinical Endocrinology and Metabolism 200388 2797-2802.

115 Joshi K, Daly AF, Beckers A \& Zacharin M. Resistant paediatric somatotropinomas due to AIP mutations: role of pegvisomant. Hormone Research in Paediatrics 201890 196-202. (https://doi. org/10.1159/000488856)

116 Daly A, Rostomyan L, Betea D, Bonneville JF, Villa C, Pellegata NS, Waser B, Reubi JC, Waeber Stephan C, Christ E et al. AIP-mutated acromegaly resistant to first-generation somatostatin analogs: long-term control with pasireotide LAR in two patients. Endocrine Connections 20198 367-377. (https://doi.org/10.1530/EC-19-0004)

117 Beckers A, Rostomyan L \& Daly AF. Overview of genetic testing in patients with pituitary adenomas. Annales d'Endocrinologie 201273 62-64. (https://doi.org/10.1016/j.ando.2012.03.028)

118 Lecoq AL, Kamenicky P, Guiochon-Mantel A \& Chanson P. Genetic mutations in sporadic pituitary adenomas - what to screen for? Nature Reviews: Endocrinology 201511 43-54. (https://doi. org/10.1038/nrendo.2014.181)

119 Caimari F \& Korbonits M. Novel genetic causes of pituitary adenomas. Clinical Cancer Research 201622 5030-5042. (https://doi. org/10.1158/1078-0432.CCR-16-0452)

120 Caimari F, Hernandez-Ramirez LC, Dang MN, Gabrovska P, Iacovazzo D, Stals K, Ellard S, Korbonits M \& International FIPA Consortium. Risk category system to identify pituitary adenoma patients with AIP mutations. Journal of Medical Genetics 201855 254-260. (https://doi.org/10.1136/jmedgenet-2017-104957)

121 Daly AF, Vanbellinghen JF, Khoo SK, Jaffrain-Rea ML, Naves LA, Guitelman MA, Murat A, Emy P, Gimenez-Roqueplo AP, Tamburrano $\mathrm{G}$ et al. Aryl hydrocarbon receptor-interacting protein gene mutations in familial isolated pituitary adenomas: analysis in 73 families. Journal of Clinical Endocrinology and Metabolism 200792 1891-1896. (https://doi.org/10.1210/jc.2006-2513)

122 Naves LA, Daly AF, Vanbellinghen JF, Casulari LA, Spilioti C, Magalhaes AV, Azevedo MF, Giacomini LA, Nascimento PP, Nunes RO et al. Variable pathological and clinical features of a large Brazilian family harboring a mutation in the aryl hydrocarbon receptorinteracting protein gene. European Journal of Endocrinology $2007 \mathbf{1 5 7}$ 383-391. (https://doi.org/10.1530/EJE-07-0533)

123 Beckers A, Petrossians P, Hanson J \& Daly AF. The causes and consequences of pituitary gigantism. Nature Reviews: Endocrinology 201814 705-720. (https://doi.org/10.1038/s41574-018-0114-1)

124 Chahal HS, Stals K, Unterlander M, Balding DJ, Thomas MG, Kumar AV, Besser GM, Atkinson AB, Morrison PJ, Howlett TA et al. AIP mutation in pituitary adenomas in the 18 th century and today. New England Journal of Medicine 2011364 43-50. (https://doi. org/10.1056/NEJMoa1008020)

125 Beckers A, Lodish MB, Trivellin G, Rostomyan L, Lee M, Faucz FR, Yuan B, Choong CS, Caberg JH, Verrua E et al. X-linked acrogigantism syndrome: clinical profile and therapeutic responses. Endocrine-Related Cancer 201522 353-367. (https://doi.org/10.1530/ ERC-15-0038)

126 Iacovazzo D, Caswell R, Bunce B, Jose S, Yuan B, HernandezRamirez LC, Kapur S, Caimari F, Evanson J, Ferrau F et al. Germline or somatic GPR101 duplication leads to X-linked acrogigantism: a clinico-pathological and genetic study. Acta Neuropathologica Communications 20164 56. (https://doi.org/10.1186/s40478-0160328-1)

127 Rodd C, Millette M, Iacovazzo D, Stiles CE, Barry S, Evanson J, Albrecht S, Caswell R, Bunce B, Jose S et al. Somatic GPR101 duplication causing X-linked Acrogigantism (XLAG)-diagnosis and management. Journal of Clinical Endocrinology and Metabolism 2016 101 1927-1930. (https://doi.org/10.1210/jc.2015-4366)

128 Naves LA, Daly AF, Dias LA, Yuan B, Zakir JC, Barra GB, Palmeira L, Villa C, Trivellin G, Junior AJ et al. Aggressive tumor growth and clinical evolution in a patient with X-linked acro-gigantism syndrome. Endocrine 201651 236-244. (https://doi.org/10.1007/ s12020-015-0804-6)

129 Daly AF, Lysy PA, Desfilles C, Rostomyan L, Mohamed A, Caberg JH, Raverot V, Castermans E, Marbaix E, Maiter D et al. GHRH excess and blockade in X-LAG syndrome. Endocrine-Related Cancer 201623 161-170. (https://doi.org/10.1530/ERC-15-0478)

130 Daly AF, Yuan B, Fina F, Caberg JH, Trivellin G, Rostomyan L, de Herder WW, Naves LA, Metzger D, Cuny T et al. Somatic mosaicism underlies X-linked acrogigantism syndrome in sporadic male subjects. Endocrine-Related Cancer 201623 221-233. (https://doi. org/10.1530/ERC-16-0082)

131 Trivellin G, Hernandez-Ramirez LC, Swan J \& Stratakis CA. An orphan G-protein-coupled receptor causes human gigantism and/or acromegaly: molecular biology and clinical correlations. Best Practice and Research: Clinical Endocrinology and Metabolism 201832 125-140. (https://doi.org/10.1016/j.beem.2018.02.004)

132 Beckers A, Rostomyan L, Potorac I, Beckers P, Daly AF \& X-LAG. How did they grow so tall? Annales d'Endocrinologiel $2017 \mathbf{7 8} 131-136$.

133 Beckers A, Fernandes D, Fina F, Novak M, Abati A, Rostomyan L, Thiry A, Ouafik L, Pasture B, Pinhasi R et al. Paleogenetic study of ancient DNA suggestive of X-linked acrogigantism. Endocrine-Related Cancer 201724 L17-L20. (https://doi.org/10.1530/ERC-16-0558)

134 Moran A, Asa SL, Kovacs K, Horvath E, Singer W, Sagman U, Reubi JC, Wilson CB, Larson R \& Pescovitz OH. Gigantism due to pituitary mammosomatotroph hyperplasia. New England 
Journal of Medicine 1990323 322-327. (https://doi.org/10.1056/ NEJM199008023230507)

135 Ferrau F, Romeo PD, Puglisi S, Ragonese M, Torre ML, Scaroni C, Occhi G, De Menis E, Arnaldi G, Trimarchi F et al. Analysis of GPR101 and AIP genes mutations in acromegaly: a multicentric study. Endocrine 201654 762-767. (https://doi.org/10.1007/s12020016-0862-4)

136 Matsumoto R, Izawa M, Fukuoka H, Iguchi G, Odake Y, Yoshida K, Bando H, Suda K, Nishizawa H, Takahashi M et al. Genetic and clinical characteristics of Japanese patients with sporadic somatotropinoma. Endocrine Journal 201663 953-963. (https://doi. org/10.1507/endocri.EJ16-0075)

137 Lecoq AL, Bouligand J, Hage M, Cazabat L, Salenave S, Linglart A, Young J, Guiochon-Mantel A, Chanson P \& Kamenicky P. Very low frequency of germline GPR101 genetic variation and no biallelic defects with AIP in a large cohort of patients with sporadic pituitary adenomas. European Journal of Endocrinology 2016174 523-530. (https://doi.org/10.1530/EJE-15-1044)

138 Trivellin G, Correa RR, Batsis M, Faucz FR, Chittiboina P, Bjelobaba I, Larco DO, Quezado M, Daly AF, Stojilkovic SS et al. Screening for GPR101 defects in pediatric pituitary corticotropinomas. EndocrineRelated Cancer 201623 357-365. (https://doi.org/10.1530/ERC-160091)

139 Wise-Oringer BK, Zanazzi GJ, Gordon RJ, Wardlaw SL, William C, Anyane-Yeboa K, Chung WK, Kohn B, Wisoff JH, David R et al. Familial X-linked Acrogigantism: postnatal outcomes and tumor pathology in a prenatally diagnosed infant and his mother. Journal of Clinical Endocrinology and Metabolism 2019104 4667-4675. (https:// doi.org/10.1210/jc.2019-00817)

140 Thakker RV. Multiple endocrine neoplasia type 1 (MEN1). Best Practice and Research: Clinical Endocrinology and Metabolism 201024 355-370. (https://doi.org/10.1016/j.beem.2010.07.003)

141 Lemmens I, Van de Ven WJ, Kas K, Zhang CX, Giraud S, Wautot V, Buisson N, De Witte K, Salandre J, Lenoir G et al. Identification of the multiple endocrine neoplasia type 1 (MEN1) gene. The European Consortium on MEN1. Human Molecular Genetics 19976 1177-1183. (https://doi.org/10.1093/hmg/6.7.1177)

142 Chandrasekharappa SC, Guru SC, Manickam P, Olufemi SE, Collins FS, Emmert-Buck MR, Debelenko LV, Zhuang Z, Lubensky IA, Liotta LA et al. Positional cloning of the gene for multiple endocrine neoplasia-type 1. Science 1997276 404-407. (https://doi. org/10.1126/science.276.5311.404)

143 Thakker RV. Multiple endocrine neoplasia type 1 (MEN1) and type 4 (MEN4). Molecular and Cellular Endocrinology 2014386 2-15. (https:// doi.org/10.1016/j.mce.2013.08.002)

144 Thakker RV, Newey PJ, Walls GV, Bilezikian J, Dralle H, Ebeling PR, Melmed S, Sakurai A, Tonelli F, Brandi ML et al. Clinical practice guidelines for multiple endocrine neoplasia type 1 (MEN1). Journal of Clinical Endocrinology and Metabolism 201297 2990-3011. (https:// doi.org/10.1210/jc.2012-1230)

145 Beckers A, Betea D, Valdes Socin H \& Stevenaert A. The treatment of sporadic versus MEN1-related pituitary adenomas. Journal of Internal Medicine 2003253 599-605. (https://doi.org/10.1046/j.13652796.2003.01164.x)

146 Verges B, Boureille F, Goudet P, Murat A, Beckers A, Sassolas G, Cougard P, Chambe B, Montvernay C \& Calender A. Pituitary disease in MEN type 1 (MEN1): data from the France-Belgium MEN1 multicenter study. Journal of Clinical Endocrinology and Metabolism 200287 457-465. (https://doi.org/10.1210/jcem.87.2.8145)

147 Marini F, Giusti F, Fossi C, Cioppi F, Cianferotti L, Masi L, Boaretto F, Zovato S, Cetani F, Colao A et al. Multiple endocrine neoplasia type 1: analysis of germline MEN1 mutations in the Italian multicenter MEN1 patient database. Endocrine 201862 215-233. (https://doi. org/10.1007/s12020-018-1566-8)

148 de Laat JM, Dekkers OM, Pieterman CR, Kluijfhout WP, Hermus AR, Pereira AM, van der Horst-Schrivers AN, Drent ML, Bisschop PH,
Havekes B et al. Long-term natural course of pituitary tumors in patients With MEN1: results from the DutchMEN1 Study Group (DMSG). Journal of Clinical Endocrinology and Metabolism 2015100 3288-3296. (https://doi.org/10.1210/JC.2015-2015)

149 Goudet P, Bonithon-Kopp C, Murat A, Ruszniewski P, Niccoli P, Menegaux F, Chabrier G, Borson-Chazot F, Tabarin A, Bouchard P et al. Gender-related differences in MEN1 lesion occurrence and diagnosis: a cohort study of 734 cases from the Groupe d'etude des Tumeurs Endocrines. European Journal of Endocrinology 2011165 97-105. (https://doi.org/10.1530/EJE-10-0950)

150 Sakurai A, Suzuki S, Kosugi S, Okamoto T, Uchino S, Miya A, Imai T, Kaji H, Komoto I, Miura D et al. Multiple endocrine neoplasia type 1 in Japan: establishment and analysis of a multicentre database. Clinical Endocrinology 201276 533-539. (https://doi.org/10.1111/ j.1365-2265.2011.04227.x)

151 Giusti F, Cianferotti L, Boaretto F, Cetani F, Cioppi F, Colao A, Davi MV, Faggiano A, Fanciulli G, Ferolla P et al. Multiple endocrine neoplasia syndrome type 1: institution, management, and data analysis of a nationwide multicenter patient database. Endocrine 201758 349-359. (https://doi.org/10.1007/s12020-0171234-4)

152 Trouillas J, Labat-Moleur F, Sturm N, Kujas M, Heymann MF, Figarella-Branger D, Patey M, Mazucca M, Decullier E, Verges B et al. Pituitary tumors and hyperplasia in multiple endocrine neoplasia type 1 syndrome (MEN1): a case-control study in a series of 77 patients versus 2509 non-MEN1 patients. American Journal of Surgical Pathology 200832 534-543. (https://doi.org/10.1097/ PAS.0b013e31815ade45)

153 Sergeant C, Jublanc C, Leclercq D, Boch AL, Bielle F, Raverot G, Daly AF, Trouillas J \& Villa C. Transdifferentiation of neuroendocrine cells: gangliocytoma associated with two pituitary adenomas of different lineage in MEN1. American Journal of Surgical Pathology 201741 849-853. (https://doi.org/10.1097/ PAS.0000000000000803)

154 Magri F, Villa C, Locatelli D, Scagnelli P, Lagonigro MS, Morbini P, Castellano M, Gabellieri E, Rotondi M, Solcia E et al. Prevalence of double pituitary adenomas in a surgical series: clinical, histological and genetic features. Journal of Endocrinological Investigation 201033 325-331. (https://doi.org/10.1007/BF03346594)

155 Uraki S, Ariyasu H, Doi A, Furuta H, Nishi M, Usui T, Yamaue H \& Akamizu T. Hypersecretion of ACTH and PRL from pituitary adenoma in MEN1, adequately managed by medical therapy. Endocrinology, Diabetes and Metabolism Case Reports 20172017 Article ID: 17-0027. (https://doi.org/10.1530/EDM-17-0027)

156 Scheithauer BW, Laws Jr ER, Kovacs K, Horvath E, Randall RV \& Carney JA. Pituitary adenomas of the multiple endocrine neoplasia type I syndrome. Seminars in Diagnostic Pathology 1987 205-211.

157 Marques NV, Kasuki L, Coelho MC, Lima CHA, Wildemberg LE \& Gadelha MR. Frequency of familial pituitary adenoma syndromes among patients with functioning pituitary adenomas in a reference outpatient clinic. Journal of Endocrinological Investigation $2017 \mathbf{4 0}$ 1381-1387. (https://doi.org/10.1007/s40618-017-0725-8)

158 Stratakis CA, Schussheim DH, Freedman SM, Keil MF, Pack SD, Agarwal SK, Skarulis MC, Weil RJ, Lubensky IA, Zhuang Z et al. Pituitary macroadenoma in a 5-year-old: an early expression of multiple endocrine neoplasia type 1. Journal of Clinical Endocrinology and Metabolism 200085 4776-4780. (https://doi.org/10.1210/ jcem.85.12.7064)

159 Subasinghe CJ, Somasundaram N, Sivatharshya P, Ranasinghe LD \& Korbonits M. Giant prolactinoma of young onset: a clue to diagnosis of MEN-1 syndrome. Case Reports in Endocrinology 20182018 2875074. (https://doi.org/10.1155/2018/2875074)

160 Philipp-Staheli J, Payne SR \& Kemp CJ. p27(Kip1): regulation and function of a haploinsufficient tumor suppressor and its misregulation in cancer. Experimental Cell Research 2001264 148-168. (https://doi.org/10.1006/excr.2000.5143) 
161 Hengst L, Dulic V, Slingerland JM, Lees E \& Reed SI. A cell cycleregulated inhibitor of cyclin-dependent kinases. PNAS 199491 5291-5295. (https://doi.org/10.1073/pnas.91.12.5291)

162 Polyak K, Lee MH, Erdjument-Bromage H, Koff A, Roberts JM, Tempst P \& Massague J. Cloning of p27Kip1, a cyclin-dependent kinase inhibitor and a potential mediator of extracellular antimitogenic signals. Cell 199478 59-66. (https://doi. org/10.1016/0092-8674(94)90572-x)

163 Alrezk R, Hannah-Shmouni F \& Stratakis CA. MEN4 and CDKN1B mutations: the latest of the MEN syndromes. Endocrine-Related Cancer 201724 T195-T208. (https://doi.org/10.1530/ERC-17-0243)

164 Agarwal SK, Mateo CM \& Marx SJ. Rare germline mutations in cyclindependent kinase inhibitor genes in multiple endocrine neoplasia type 1 and related states. Journal of Clinical Endocrinology and Metabolism 2009 94 1826-1834. (https://doi.org/10.1210/jc.2008-2083)

165 Georgitsi M, Raitila A, Karhu A, van der Luijt RB, Aalfs CM, Sane T, Vierimaa O, Makinen MJ, Tuppurainen K, Paschke R et al. Germline CDKN1B/p27Kip1 mutation in multiple endocrine neoplasia. Journal of Clinical Endocrinology and Metabolism 200792 3321-3325. (https:// doi.org/10.1210/jc.2006-2843)

166 Molatore S, Marinoni I, Lee M, Pulz E, Ambrosio MR, degli Uberti EC, Zatelli MC \& Pellegata NS. A novel germline CDKN1B mutation causing multiple endocrine tumors: clinical, genetic and functional characterization. Human Mutation 201031 E1825-E1835. (https:// doi.org/10.1002/humu.21354)

167 Dahia PL, Aguiar RC, Honegger J, Fahlbush R, Jordan S, Lowe DG, $\mathrm{Lu}$ X, Clayton RN, Besser GM \& Grossman AB. Mutation and expression analysis of the p27/kip1 gene in corticotrophin-secreting tumours. Oncogene 199816 69-76. (https://doi.org/10.1038/ sj.onc.1201516)

168 Tichomirowa MA, Lee M, Barlier A, Daly AF, Marinoni I, Jaffrain-Rea ML, Naves LA, Rodien P, Rohmer V, Faucz FR et al. Cyclin-dependent kinase inhibitor 1B (CDKN1B) gene variants in AIP mutation-negative familial isolated pituitary adenoma kindreds. Endocrine-Related Cancer 201219 233-241. (https://doi.org/10.1530/ERC-11-0362)

169 Carney JA, Gordon H, Carpenter PC, Shenoy BV \& Go VL. The complex of myxomas, spotty pigmentation, and endocrine overactivity. Medicine 198564 270-283. (https://doi. org/10.1097/00005792-198507000-00007)

170 Carney JA, Hruska LS, Beauchamp GD \& Gordon H. Dominant inheritance of the complex of myxomas, spotty pigmentation, and endocrine overactivity. Mayo Clinic Proceedings 198661 165-172. (https://doi.org/10.1016/s0025-6196(12)61843-6)

171 Kamilaris CDC, Faucz FR, Voutetakis A \& Stratakis CA. Carney complex. Experimental and Clinical Endocrinology and Diabetes 2019 127 156-164. (https://doi.org/10.1055/a-0753-4943)

172 Kirschner LS, Carney JA, Pack SD, Taymans SE, Giatzakis C, Cho YS, Cho-Chung YS \& Stratakis CA. Mutations of the gene encoding the protein kinase A type I-alpha regulatory subunit in patients with the Carney complex. Nature Genetics 200026 89-92. (https://doi. org/10.1038/79238)

173 Bertherat J, Horvath A, Groussin L, Grabar S, Boikos S, Cazabat L, Libe R, Rene-Corail F, Stergiopoulos S, Bourdeau I et al. Mutations in regulatory subunit type $1 \mathrm{~A}$ of cyclic adenosine $5^{\prime}$-monophosphatedependent protein kinase (PRKAR1A): phenotype analysis in 353 patients and 80 different genotypes. Journal of Clinical Endocrinology and Metabolism 200994 2085-2091. (https://doi.org/10.1210/jc.2008-2333)

174 Stratakis CA, Carney JA, Lin JP, Papanicolaou DA, Karl M, Kastner DL, Pras E \& Chrousos GP. Carney complex, a familial multiple neoplasia and lentiginosis syndrome. Analysis of 11 kindreds and linkage to the short arm of chromosome 2. Journal of Clinical Investigation 1996 97 699-705. (https://doi.org/10.1172/JCI118467)

175 Forlino A, Vetro A, Garavelli L, Ciccone R, London E, Stratakis CA \& Zuffardi O. PRKACB and Carney complex. New England Journal of Medicine 2014370 1065-1067. (https://doi.org/10.1056/ NEJMc1309730)
176 Kirschner LS. PRKAR1A and the evolution of pituitary tumors. Molecular and Cellular Endocrinology 2010326 3-7. (https://doi. org/10.1016/j.mce.2010.04.027)

177 Kaltsas GA, Kola B, Borboli N, Morris DG, Gueorguiev M, Swords FM, Czirjak S, Kirschner LS, Stratakis CA, Korbonits M et al. Sequence analysis of the PRKAR1A gene in sporadic somatotroph and other pituitary tumours. Clinical Endocrinology 200257 443-448. (https:// doi.org/10.1046/j.1365-2265.2002.01643.x)

178 Larkin SJ, Ferrau F, Karavitaki N, Hernandez-Ramirez LC, Ansorge O, Grossman AB \& Korbonits M. Sequence analysis of the catalytic subunit of PKA in somatotroph adenomas. European Journal of Endocrinology 2014171 705-710. (https://doi.org/10.1530/EJE-14-0545)

179 Yamasaki H, Mizusawa N, Nagahiro S, Yamada S, Sano T, Itakura M \& Yoshimoto K. GH-secreting pituitary adenomas infrequently contain inactivating mutations of PRKAR1A and LOH of 17q23-24. Clinical Endocrinology 200358 464-470. (https://doi.org/10.1046/j.13652265.2003.01740.x)

180 Stratakis CA, Matyakhina L, Courkoutsakis N, Patronas N, Voutetakis A, Stergiopoulos S, Bossis I \& Carney JA. Pathology and molecular genetics of the pituitary gland in patients with the 'complex of spotty skin pigmentation, myxomas, endocrine overactivity and schwannomas' (Carney complex). Frontiers of Hormone Research 200432 253-264.

181 Lonser RR, Mehta GU, Kindzelski BA, Ray-Chaudhury A, Vortmeyer AO, Dickerman R \& Oldfield EH. Surgical management of Carney complex-associated pituitary pathology. Neurosurgery $2017 \mathbf{8 0}$ 780-786. (https://doi.org/10.1227/NEU.0000000000001384)

182 Albright F, Butler AM, Hampton AO \& Smith P. Syndrome characterized by osteitis fibrosa disseminata, areas of pigmentation and endocrine dysfunction, with precocious puberty in females. New England Journal of Medicine 1937216 727-746. (https://doi. org/10.1056/NEJM193704292161701)

183 McCune DJ \& Bruch H. Osteodystrophia fibrosa. American Journal of Diseases of Children $1937 \mathbf{5 4}$ 806. (https://doi.org/10.1001/ archpedi.1937.01980040110009)

184 Weinstein LS, Shenker A, Gejman PV, Merino MJ, Friedman E \& Spiegel AM. Activating mutations of the stimulatory G protein in the McCune-Albright syndrome. New England Journal of Medicine 1991 325 1688-1695. (https://doi.org/10.1056/NEJM199112123252403)

185 Schwindinger WF, Francomano CA \& Levine MA. Identification of a mutation in the gene encoding the alpha subunit of the stimulatory $\mathrm{G}$ protein of adenylyl cyclase in McCune-Albright syndrome. PNAS 199289 5152-5156. (https://doi.org/10.1073/pnas.89.11.5152)

186 Akintoye SO, Chebli C, Booher S, Feuillan P, Kushner H, Leroith D, Cherman N, Bianco P, Wientroub S, Robey PG et al. Characterization of gsp-mediated growth hormone excess in the context of McCuneAlbright syndrome. Journal of Clinical Endocrinology and Metabolism 200287 5104-5112. (https://doi.org/10.1210/jc.2001-012022)

187 Boyce AM, Glover M, Kelly MH, Brillante BA, Butman JA, Fitzgibbon EJ, Brewer CC, Zalewski CK, Cutler Peck CM, Kim HJ et al. Optic neuropathy in McCune-Albright syndrome: effects of early diagnosis and treatment of growth hormone excess. Journal of Clinical Endocrinology and Metabolism 201398 E126-E134. (https:// doi.org/10.1210/jc.2012-2111)

188 Salenave S, Boyce AM, Collins MT \& Chanson P. Acromegaly and McCune-Albright syndrome. Journal of Clinical Endocrinology and Metabolism 201499 1955-1969. (https://doi.org/10.1210/jc.20133826)

189 Vasilev V, Daly AF, Thiry A, Petrossians P, Fina F, Rostomyan L, Silvy M, Enjalbert A, Barlier A \& Beckers A. McCune-Albright syndrome: a detailed pathological and genetic analysis of disease effects in an adult patient. Journal of Clinical Endocrinology and Metabolism 201499 E2029-E2038. (https://doi.org/10.1210/jc.2014-1291)

190 Belsuzarri TA, Araujo JF, Melro CA, Neves MW, Navarro JN, Brito LG, Pontelli LO, de Abreu Mattos LG, Goncales TF \& Zeviani WM. McCune-Albright syndrome with craniofacial dysplasia: clinical 
review and surgical management. Surgical Neurology International 20167 S165-S169. (https://doi.org/10.4103/2152-7806.178567)

191 Galland F, Kamenicky P, Affres H, Reznik Y, Pontvert D, Le Bouc Y, Young J \& Chanson P. McCune-Albright syndrome and acromegaly: effects of hypothalamopituitary radiotherapy and/or pegvisomant in somatostatin analog-resistant patients. Journal of Clinical Endocrinology and Metabolism 200691 4957-4961. (https://doi. org/10.1210/jc.2006-0561)

192 Iversen K. Acromegaly associated with phaeochromocytoma. Acta Medica Scandinavica 1952142 1-5. (https://doi. $\operatorname{org} / 10.1111 / j .0954-6820.1952 . t b 13837 . x)$

193 O’Toole SM, Denes J, Robledo M, Stratakis CA \& Korbonits M. 15 years of paraganglioma: the association of pituitary adenomas and phaeochromocytomas or paragangliomas. Endocrine-Related Cancer 201522 T105-T122. (https://doi.org/10.1530/ERC-15-0241)

194 Roszko KL, Blouch E, Blake M, Powers JF, Tischler AS, Hodin R, Sadow P \& Lawson EA. Case report of a prolactinoma in a patient with a novel MAX mutation and bilateral pheochromocytomas. Journal of the Endocrine Society 20171 1401-1407. (https://doi. org/10.1210/js.2017-00135)

195 Daly AF, Castermans E, Oudijk L, Guitelman MA, Beckers P, Potorac I, Neggers SJCMM, Sacre N, van der Lely AJ, Bours V et al. Pheochromocytomas and pituitary adenomas in three patients with MAX exon deletions. Endocrine-Related Cancer 201825 L37-L42. (https://doi.org/10.1530/ERC-18-0065)

196 Tufton N, Roncaroli F, Hadjidemetriou I, Dang MN, Denes J, Guasti L, Thom M, Powell M, Baldeweg SE, Fersht N et al. Pituitary carcinoma in a patient with an SDHB mutation. Endocrine Pathology 201728 320-325. (https://doi.org/10.1007/s12022-017-9474-7)

197 Maher M, Roncaroli F, Mendoza N, Meeran K, Canham N, KosickaSlawinska M, Bernhard B, Collier D, Drummond J, Skordilis K et al. A patient with a germline SDHB mutation presenting with an isolated pituitary macroprolactinoma. Endocrinology, Diabetes and Metabolism Case Reports 20182018 Article ID: 18-0078. (https:// doi.org/10.1530/EDM-18-0078)

198 Brahma A, Heyburn P \& Swords F. Familial prolactinomas occurring in association with SDHB mutation positive paraganglioma. Endocrine Abstracts 200919 P239.

199 Rutter J, Winge DR \& Schiffman JD. Succinate dehydrogenase assembly, regulation and role in human disease. Mitochondrion 2010 10 393-401. (https://doi.org/10.1016/j.mito.2010.03.001)

200 Favier J \& Gimenez-Roqueplo AP. Pheochromocytomas: the (pseudo)hypoxia hypothesis. Best Practice and Research: Clinical Endocrinology and Metabolism 201024 957-968. (https://doi.org/10.1016/j. beem.2010.10.004)

201 Denes J, Swords F, Rattenberry E, Stals K, Owens M, Cranston T, Xekouki P, Moran L, Kumar A, Wassif C et al. Heterogeneous genetic background of the association of pheochromocytoma/paraganglioma and pituitary adenoma: results from a large patient cohort. Journal of Clinical Endocrinology and Metabolism 2015100 E531-E541. (https:// doi.org/10.1210/jc.2014-3399)

202 Kobza AO, Dizon S \& Arnaout A. Case report of bilateral phochromocytomas due to a novel MAX mutation in a patient known to have a pituitary prolactinoma. AACE Clinical Case Reports 20184 e453-e456. (https://doi.org/10.4158/ACCR-2018-0146)

203 Papathomas TG, Gaal J, Corssmit EP, Oudijk L, Korpershoek E, Heimdal K, Bayley JP, Morreau H, van Dooren M, Papaspyrou K et al. Non-pheochromocytoma (PCC)/paraganglioma (PGL) tumors in patients with succinate dehydrogenase-related PCC-PGL syndromes: a clinicopathological and molecular analysis. European Journal of Endocrinology 2014170 1-12. (https://doi.org/10.1530/EJE-13-0623)
204 Gill AJ, Toon CW, Clarkson A, Sioson L, Chou A, Winship I, Robinson BG, Benn DE, Clifton-Bligh RJ \& Dwight T. Succinate dehydrogenase deficiency is rare in pituitary adenomas. American Journal of Surgical Pathology 201438 560-566.

205 Tadini G, Milani D, Menni F, Pezzani L, Sabatini C \& Esposito S. Is it time to change the neurofibromatosis 1 diagnostic criteria? European Journal of Internal Medicine 201425 506-510. (https://doi. org/10.1016/j.ejim.2014.04.004)

206 Martini AE, Zolton JR \& DeCherney AH. Isolated absent thelarche in a patient with neurofibromatosis Type 1 and acromegaly. Obstetrics and Gynecology 2018131 96-99. (https://doi.org/10.1097/ AOG.0000000000002389)

207 Cambiaso P, Galassi S, Palmiero M, Mastronuzzi A, Del Bufalo F, Capolino R, Cacchione A, Buonuomo PS, Gonfiantini MV, Bartuli A et al. Growth hormone excess in children with neurofibromatosis type-1 and optic glioma. American Journal of Medical Genetics: Part A 2017173 2353-2358. (https://doi.org/10.1002/ajmg.a.38308)

208 Hannah-Shmouni F \& Stratakis CA. Growth hormone excess in neurofibromatosis 1. Genetics in Medicine 201921 1254-1255. (https://doi.org/10.1038/s41436-018-0312-1)

209 Scheithauer BW, Kovacs K, Horvath E, Kim DS, Osamura RY, Ketterling RP, Lloyd RV \& Kim OL. Pituitary blastoma. Acta Neuropathologica 2008116 657-666. (https://doi.org/10.1007/s00401008-0388-9)

210 de Kock L, Sabbaghian N, Plourde F, Srivastava A, Weber E, BouronDal Soglio D, Hamel N, Choi JH, Park SH, Deal CL et al. Pituitary blastoma: a pathognomonic feature of germ-line DICER1 mutations. Acta Neuropathologica 2014128 111-122. (https://doi.org/10.1007/ s00401-014-1285-z)

211 Sahakitrungruang T, Srichomthong C, Pornkunwilai S, Amornfa J, Shuangshoti S, Kulawonganunchai S, Suphapeetiporn K \& Shotelersuk V. Germline and somatic DICER1 mutations in a pituitary blastoma causing infantile-onset Cushing's disease. Journal of Clinical Endocrinology and Metabolism 201499 E1487-E1492. (https://doi.org/10.1210/jc.2014-1016)

212 Hernandez-Ramirez LC, Gam R, Valdes N, Lodish MB, Pankratz N, Balsalobre A, Gauthier Y, Faucz FR, Trivellin G, Chittiboina P et al. Loss-of-function mutations in the CABLES1 gene are a novel cause of Cushing's disease. Endocrine-Related Cancer 201724 379-392. (https://doi.org/10.1530/ERC-17-0131)

213 Roussel-Gervais A, Couture C, Langlais D, Takayasu S, Balsalobre A, Rueda BR, Zukerberg LR, Figarella-Branger D, Brue T \& Drouin J. The Cables1 gene in glucocorticoid regulation of pituitary corticotrope growth and Cushing disease. Journal of Clinical Endocrinology and Metabolism 2016101 513-522. (https://doi.org/10.1210/jc.20153324)

214 Boronat M, Carrillo A, Ojeda A, Estrada J, Ezquieta B, Marin F \& Novoa FJ. Clinical manifestations and hormonal profile of two women with Cushing's disease and mild deficiency of 21-hydroxylase. Journal of Endocrinological Investigation 200427 583-590. (https://doi.org/10.1007/BF03347484)

215 Haase M, Schott M, Kaminsky E, Ludecke DK, Saeger W, Fritzen R, Schinner S, Scherbaum WA \& Willenberg HS. Cushing's disease in a patient with steroid 21-hydroxylase deficiency. Endocrine Journal 201158 699-706. (https://doi.org/10.1507/endocrj.k11e-097)

216 De Menis E, Roncaroli F, Calvari V, Chiarini V, Pauletto P, Camerino G \& Cremonini N. Corticotroph adenoma of the pituitary in a patient with X-linked adrenal hypoplasia congenita due to a novel mutation of the DAX-1 gene. European Journal of Endocrinology 2005153 211-215. (https://doi.org/10.1530/ eje.1.01958)

Received 2 August 2019

Revised version received 27 September 2019

Accepted 17 October 2019 